\title{
Genetic and genomic resources, and breeding for accelerating improvement of small millets: current status and future interventions
}

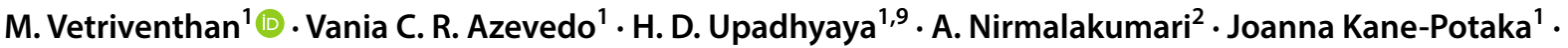 \\ S. Anitha ${ }^{1} \cdot$ S. Antony Ceasar ${ }^{3} \cdot$ M. Muthamilarasan ${ }^{4} \cdot$ B. Venkatesh Bhat ${ }^{5} \cdot$ K. Hariprasanna ${ }^{5}$. \\ Amasiddha Bellundagi ${ }^{5}$. Deepika Cheruku ${ }^{5}$. C. Backiyalakshmi ${ }^{6}$. Dipak Santra ${ }^{7}$. C. Vanniarajan ${ }^{8} \cdot$ Vilas A. Tonapi $^{5}$
}

Received: 1 March 2020 / Accepted: 29 May 2020 / Published online: 4 July 2020

(c) The Author(s) 2020

\begin{abstract}
Current agricultural and food systems encourage research and development on major crops, neglecting regionally important minor crops. Small millets include a group of small- seeded cereal crops of the grass family Poaceae. This includes finger millet, foxtail millet, proso millet, barnyard millet, kodo millet, little millet, teff, fonio, job's tears, guinea millet, and browntop millet. Small millets are an excellent choice to supplement major staple foods for crop and dietary diversity because of their diverse adaptation on marginal lands, less water requirement, lesser susceptibility to stresses, and nutritional superiority compared to major cereal staples. Growing interest among consumers about healthy diets together with climate-resilient features of small millets underline the necessity of directing more research and development towards these crops. Except for finger millet and foxtail millet, and to some extent proso millet and teff, other small millets have received minimal research attention in terms of development of genetic and genomic resources and breeding for yield enhancement. Considerable breeding efforts were made in finger millet and foxtail millet in India and China, respectively, proso millet in the United States of America, and teff in Ethiopia. So far, five genomes, namely foxtail millet, finger millet, proso millet, teff, and Japanese barnyard millet, have been sequenced, and genome of foxtail millet is the smallest (423-510 Mb) while the largest one is finger millet $(1.5 \mathrm{~Gb})$. Recent advances in phenotyping and genomics technologies, together with available germplasm diversity, could be utilized in small millets improvement. This review provides a comprehensive insight into the importance of small millets, the global status of their germplasm, diversity, promising germplasm resources, and breeding approaches (conventional and genomic approaches) to accelerate climate-resilient and nutrient-dense small millets for sustainable agriculture, environment, and healthy food systems.
\end{abstract}

Keywords Small millets $\cdot$ Climate-resilience $\cdot$ Genomics $\cdot$ Breeding $\cdot$ Germplasm $\cdot$ Underutilized crops

\section{Introduction}

The global population is projected to reach 9.8 billion by 2050 , will require a $60-70 \%$ increase in food production from the current level, posing a significant challenge to feed growing population. On the other hand, among the

Corresponding Editor: Manoj Prasad.

Electronic supplementary material The online version of this article (https://doi.org/10.1007/s13237-020-00322-3) contains supplementary material, which is available to authorized users.

M. Vetriventhan

M.Vetriventhan@cgiar.org

Extended author information available on the last page of the article major staple food crops, three cereals, rice [Oryza sativa L.], wheat [Triticum aestivum L.], and maize [Zea mays L.] provide $>60 \%$ of plant-based human energy intake, and this is greater in several countries in Asia [22, 177]. Although these major staple cereal grains make up a critical portion of many diets, they possess a lower concentration of mineral elements (micro and macro nutrients). The hidden hunger due to micronutrients deficiency affects about 2 billion people globally $[16,102,142]$. This is mainly becasue of our heavy reliance on only a few major food staples. Therefore, there is a need for a big transformation of current agriculture and food systems towards greater diversity (crops and diets) by promoting cultivation and consumption of traditionally and regionally important underutilized, climate-resilient 
and nutrient-dense crops for sustainable agriculture and healthy diets [177].

Small millets, also known as minor millets, are a group of small- seeded cereal crops of the grass family Poaceae. This includes finger millet (Eleusine coracana (L.) Gaertn.), foxtail millet (Setaria italica (L.) P. Beauv.), proso millet (Panicum miliaceum L.), barnyard millet (Echinochloa crus-galli (L.) P. Beauv. and Echinochloa colona (L.) Link), kodo millet (Paspalum scrobiculatum L.), little millet (Panicum sumatrense Roth. ex. Roem. \& Schult.), teff (Eragrostis tef (Zucc.) Trotter], fonio (Digitaria exilis Stapf and D. iburua Stapf.), job's tears (Coix lacryma-jobi L.), guinea millet (Brachiaria deflexa (Schumach.) C.E.Hubb. ex Robyns, = Urochloa deflexa (Schumach.) H.Scholz), and browntop millet $($ Brachiaria ramosa $(\mathrm{L}$.) Stapf.=Urochloa ramosa (L.) T.Q. Nguyen) (Table 1, Figure S-1). Small millets are known for their climate-resilient features, including their broader adaptation to diverse ecological conditions, lesser water requirement, lower occurrence of insect pests and diseases, and minimum vulnerability to environmental stresses [14, 49, 150]. Small millets are important crops of rainfed areas in semi-arid regions. Currently they are grown on a limited area representing a small portion of global millet production, because of the shift from traditional crops to cash crops. Some of these small millets are considered as weeds, particularly the wild forms (http://tropical.theferns. info/; https://www.cabi.org/isc); however, they are the crops of local importance that provide reliable yields on marginal lands, and contribute significantly to the food security.

Small millets grains are versatile that can easily be incorporated into existing rice or maize-based diets or as substitutes for rice in existing recipes. They also serve as major food components in various traditional foods and beverages, and are ingredients in a variety of multigrain and glutenfree cereal products. Millets are also consumed as fermented beverages making increased nutrients availability, including protein and mineral bioavailability, and digestibility, and reduces antinutritional factors [124]. Because of growing sedentary lifestyle and its associated health issues, consumers are seeking more nutrient-rich foods that are both tasty and healthy. Small millets fit the bill as a healthy food choice because they provide high energy, high dietary fibre, protein with balanced amino acid profile, many essential minerals, vitamins, antioxidants, and have a low glycemic index (GI) $[32,45,83,145]$. Because of these features, they are called as 'Smart-Food Crops' and 'nutri-cereals'. The nutrient content of millets vary with variety and type. However, regardless of variety, finger millet grains contain exceptionally high calcium (>350 mg per $100 \mathrm{~g}$ ) followed by teff (159 mg per $100 \mathrm{~g}$ ); proso millet, job's tears, foxtail millet and barnyard millet are rich in protein $(>10 \%)$; foxtail millet, little millet and job's tears are rich in fat $(>4.0 \%)$; barnyard millet, little millet, foxtail millet and fonio are rich in crude fibre (6.7-13.6\%), little and barnyard millets are rich in iron (9.3-18.6 mg per $100 \mathrm{~g}$ ) compared to other major cereals such as rice, wheat and sorghum [21, 145]. Grain iron, zinc, calcium, protein and crude fiber contents among small millets are presented in Fig. 1. Small millets play a strategic role as a staple food for the poor, and lately, as a healthy food for those in urban areas, underline the necessity of directing more research and development towards these crops.

\section{Origin, domestication and taxonomy}

Small millets belong to nine different genera of the grass family Poaceae. Figure 2 shows the taxonomical classification of small millets, together with major cereals, and pseudo-cereals. Table 1 presents a list of small millets and their scientific name, chromosome number, place of domestication and distribution. Cultivated germplasm of finger millet, foxtail millet, proso millet, kodo millet, little millet, and barnyard millet can be subdivided into races, and subraces, based on panicle morphology and shape (Table 1). No racial classification has been reported in other small millets. However, teff can be classified on the basis of seed color: ivory (white), qey (red/brown) and sergegna (mixed). In fonio, five morpho-types have been recognized namely gracilis, stricta, rustica, mixta, and densa on the basis of morphology [21]. In job's tears, three morphologically distinct forms have been reported, including one cultivated type, var. ma-yuen and two wild types, var. stenocarpa and var. monilifer [8]. Morphotypes or races are not known in guinea millet and browntop millet. The divergence of small millets is also seen in terms of their chromosome number and ploidy level which range from the diploid foxtail millet $(2 n=2 x=14)$ to the hexaploid barnyard millet $(2 n=6 x=54)$. All these small millets are originated and domesticated in Asia, and/ or Africa, and distributed globally, either as food crop, or feed, and/or as weeds/grasses (Table 1).

\section{Global status of small millets cultivation}

The area, production and productivity of small millets are not well documented and mostly reported together as 'millets', unlike major crops. Foxtail millet is the second most produced millet after pearl millet and is an important food for human consumption in China, India, Korea, Japan, and Nepal [10, 45]. It is widely cultivated in Asia, Europe, North America, Australia, and North Africa for grains or forage. China ranks first in foxtail millet production (1.81 million (m) tons (t) from $0.72 \mathrm{~m}$ hectares (ha) during 2014). However, its area under cultivation has fallen drastically in the last 65 years, from $9.2 \mathrm{~m}$ ha in 1949 to $0.72 \mathrm{~m}$ ha in 2014 , resulting in a decline in production from $7.79 \mathrm{~m} \mathrm{t}$ to $1.81 \mathrm{~m} \mathrm{t}$, 


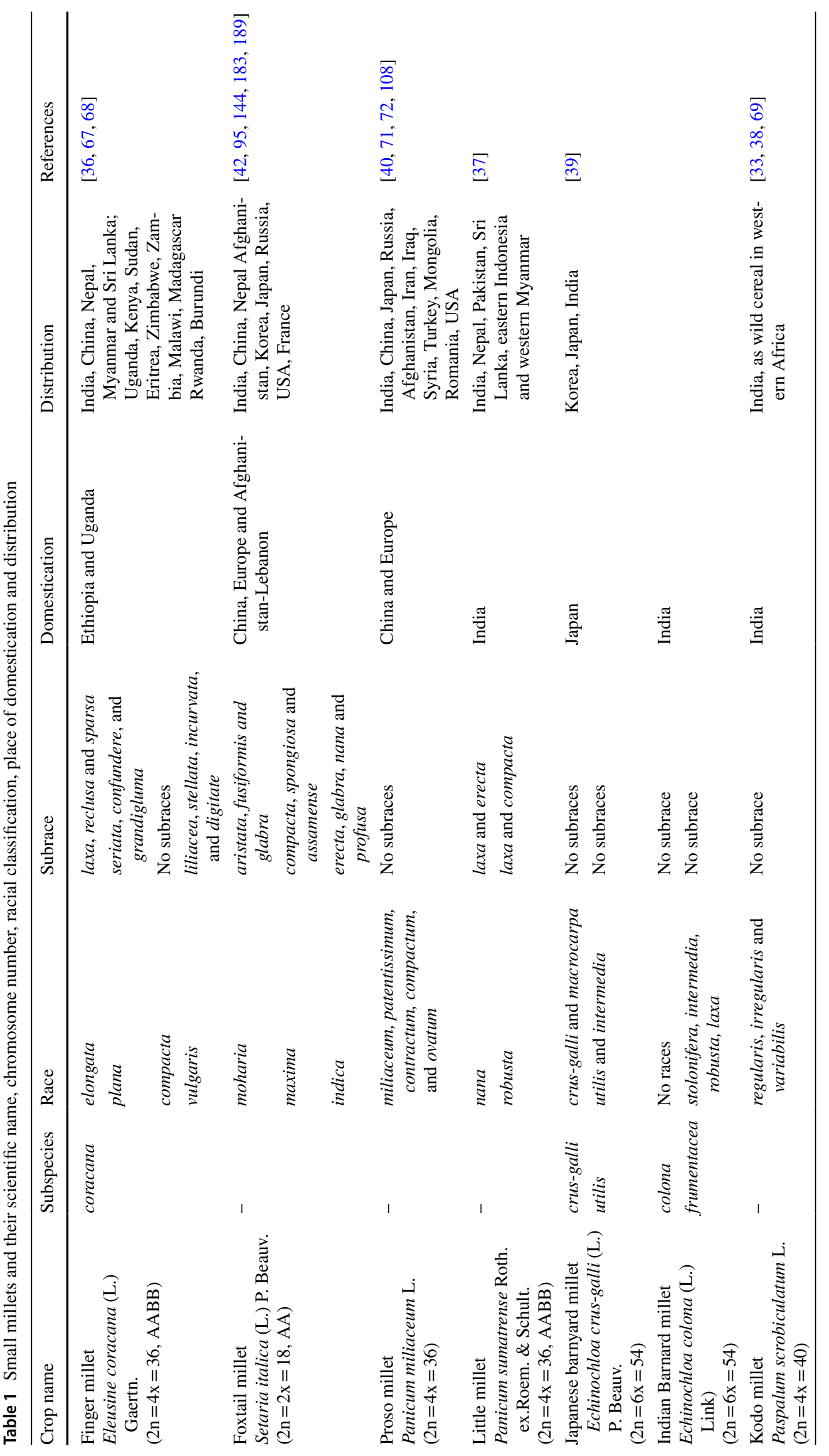




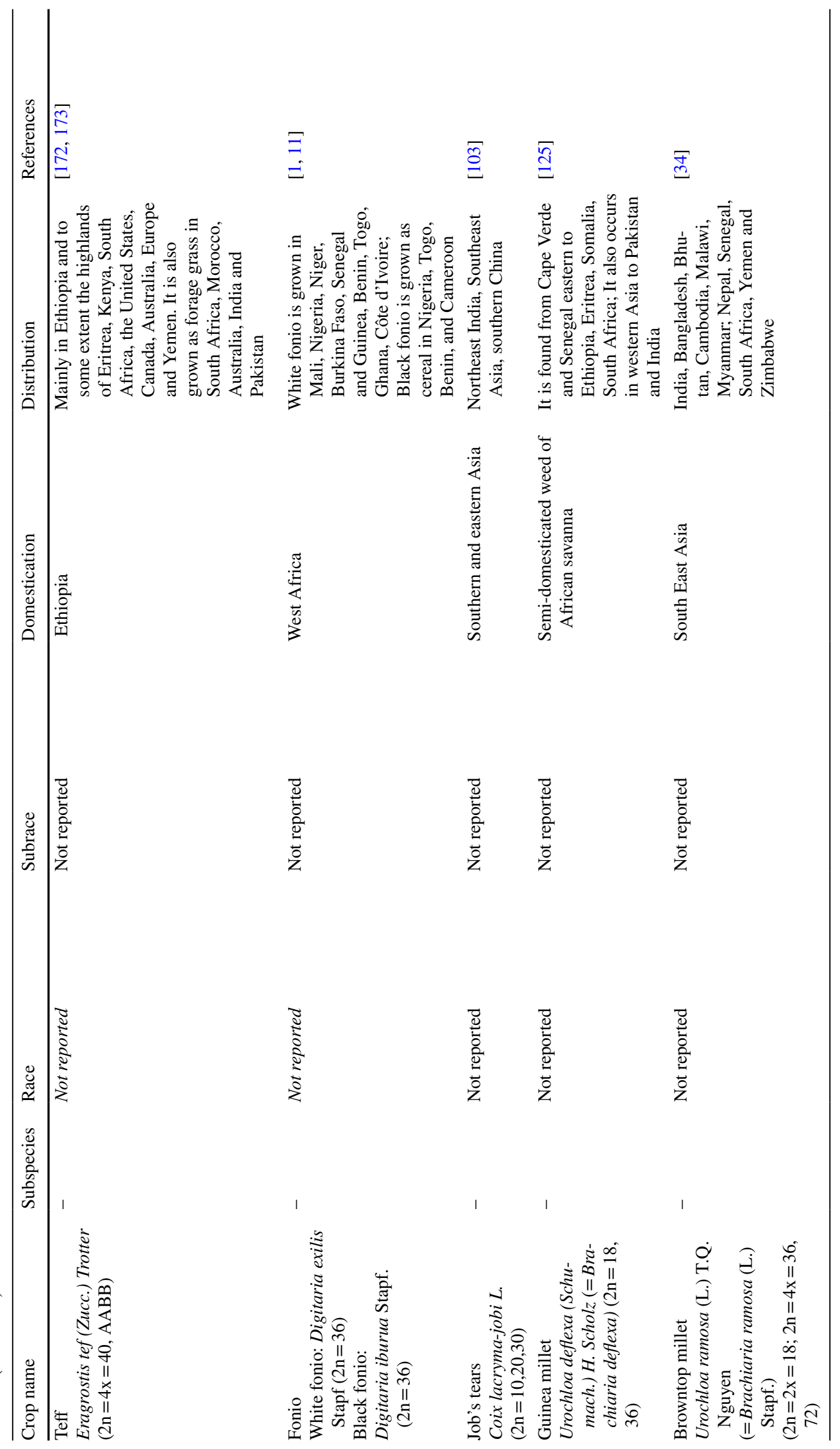




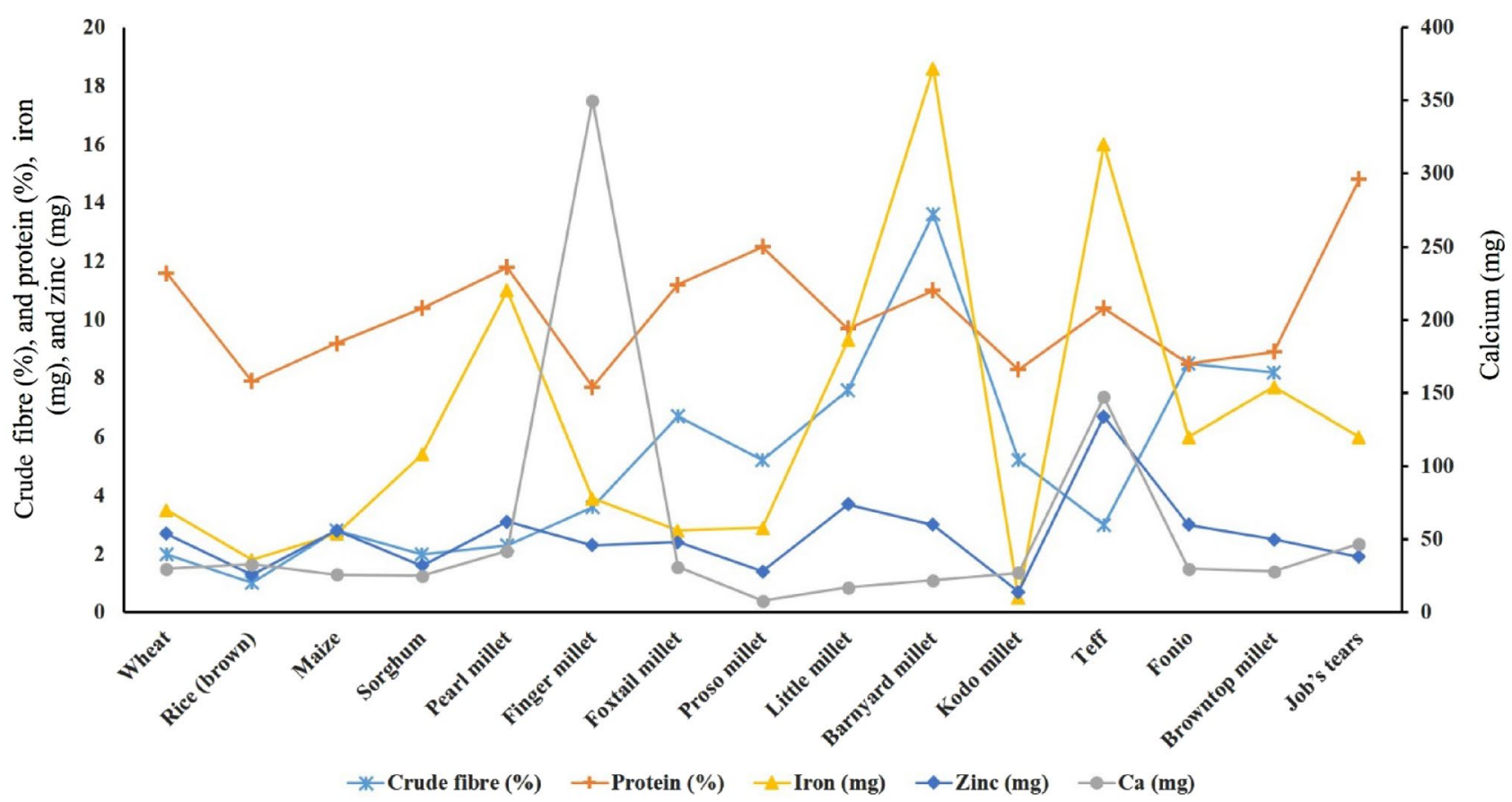

Fig. 1 Nutrient composition of small millets in comparison with major cereals (100 g edible part at 12\% moisture) Source: [13, 46, 148, 185]; http://krishikosh.egranth.ac.in/handle/1/5810027060

respectively [43]. In India, foxtail millet was once an important crop in rainfed areas because of its drought tolerance. However, its area fell by more than half during the 1990s, mainly due to the introduction of more remunerative crops [63]. At present, in India it is cultivated on about $0.07 \mathrm{~m}$ ha with a production of $0.05 \mathrm{~m} \mathrm{t}$ [18]. Finger millet is estimated to be cultivated on 4.0-4.5 m ha globally, with a production of about $4.5 \mathrm{~m} \mathrm{t}$ [54]. The important finger millet growing countries in eastern and southern Africa are the sub-humid regions of Ethiopia, Kenya, Tanzania, Zambia, Malawi, Democratic Republic of the Congo, Uganda and Zimbabwe, while in South Asia, the crop is widely cultivated in India, Nepal, Bhutan and Sri Lanka [47]. Proso millet is grown in Asia, Australia, North America, Europe, and Africa, and used for feeding birds and livestock in developed countries, and for food in some parts of Asia [139]. Proso millet is cultivated on about $0.82 \mathrm{~m}$ ha in Russia, $0.32 \mathrm{~m}$ ha in China [43], $0.20 \mathrm{~m}$ ha in USA [60], $0.03 \mathrm{~m}$ ha in India [18] and $0.002 \mathrm{~m}$ ha in Korea [131]. The USA is among the top producer, and exports $15-20 \%$ of its annual production to over 70 countries [60]. Globally, fonio was cultivated on $0.96 \mathrm{~m}$ ha in 2017 with a production of $0.67 \mathrm{~m} \mathrm{t}$. It is largely cultivated in Guinea over an area of $0.67 \mathrm{~m}$ ha with a production of $0.51 \mathrm{~m} \mathrm{t}$, followed by Nigeria $(0.19 \mathrm{~m}$ ha and $0.08 \mathrm{~m}$ tons). Among the other countries growing fonio are Mali, Burkina Faso, Ivory Coast, Niger, Senegal, Benin, and Guinea-Bissau (http://www.fao.org/faostat/en/\#data, accessed on 20 March 2019).
Other minor or regionally important crops include barnyard millet, kodo millet, little millet, browntop millet, teff, and job's tears. Barnyard millet is an important crop in India, China, Japan and Korea, where it is being used for human consumption as well as fodder [163]. In India, barnyard millet is grown on $0.146 \mathrm{~m}$ ha with a production of $0.151 \mathrm{~m} \mathrm{t}$ [18]. Kodo millet is grown in upland rice regions in India, Indonesia, Philippines, Thailand and Vietnam, and also in Bangladesh and Myanmar [64]. At present kodo millet (area $0.20 \mathrm{~m}$ ha and production $0.084 \mathrm{~m} \mathrm{t}$ ) and little millet (area $0.26 \mathrm{~m}$ ha and $0.12 \mathrm{~m} \mathrm{t}$ ) are mainly cultivated in India [18]. Teff is largely grown as a major cereal crop in Ethiopia, where it occupied $3.02 \mathrm{~m}$ ha in 2017, ranking first among all the cereals cultivated in the country [93]. Teff also spreading to other countries such as Australia, Cameroon, Canada, China, India, Netherlands, South Africa, the UK, Uganda and the USA. However, production statistics are not available [93]. Job's tears is grown mainly in southeast Asian countries, including China, Vietnam, Laos, Japan, and Korea. In China, it is widely distributed in nearly all the provinces except Qinghai and Tibet, and mainly grown in Guizhou, Yunnan, Guangxi, and Fujian. It is estimated to be cultivated over $0.07 \mathrm{~m}$ ha with a grain yield of $0.22 \mathrm{~m} \mathrm{t}$ [43]. Browntop millet is grown mostly in southern India [19], and also grown in some parts of the USA as a fodder crop and bird feed. 


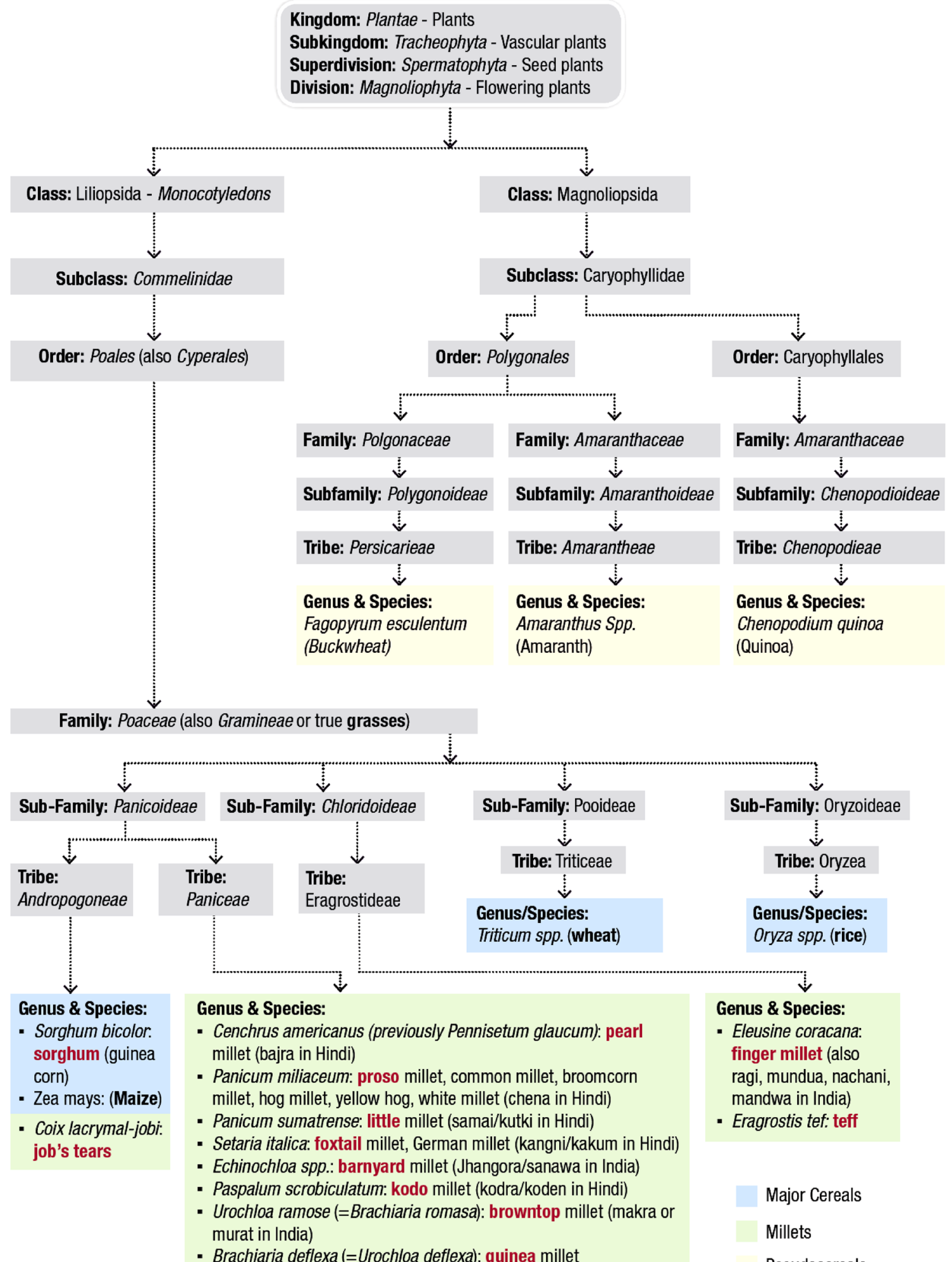

- Digitaria exilis and D. iburua, white fonio and black fonio, raishan,

Pseudocereals

Fig. 2 Taxonomical classification of small millets and other major cereals and millets, and pseudo-cereals [Note: "Millet" is a common term to categorize small-seeded grasses that are often called dryland cereals. The grasses most commonly referred to as millets are: Major millet (pearl millet) and small millets (finger millet, foxtail millet, proso millet, little millet, barnyard millet, kodo millet, browntop millet, fonio, teff and job's tears, and guinea millet; and sometimes sorghum is categorized as a major millet - this is typically included in the common definition of millets in India but less so in other countries]. 


\section{Germplasm resources}

\section{Global status of germplasm resources}

Diversity in crop cultivars is important for sustainable agriculture. Germplasm provides the required variability for crop improvement. The narrow genetic base of cultivars leads to increased risk of vulnerability resulting in crop failure due to insect pests and disease epidemics or unpredictable climate effects. Globally, about 133,849 cultivated germplasm of small millets are conserved in genebanks, while other species of these genera include 30,627 accessions (Table 2). Region-wise, a majority of accessions are conserved in Asia (64.4\%), followed by Africa (13.8\%), and Europe (13.5\%). These figures could vary slightly due to considerable portion of germplasm that could be duplicates within and/or between the genebanks. The major collections of foxtail millet germplasm are conserved in China, India, France, and Japan, while India and African countries such as Kenya, Ethiopia, Uganda, and Zambia have major finger millet collections. Similarly, the major collections of proso millet germplasm are in the Russia, China, Ukraine, and India; barnyard millet in Japan and
India; kodo millet in India and USA; and little millet in India [171, 175]. Major collections of teff, fonio and job's tears were conserved in Ethiopia, USA and Japan, respectively. The largest germplasm collection of small millets conserved by institute are: finger millet (9522), kodo millet (2180) and little millet (1253) at National Bureau of Plant Genetic Resources (NBPGR, India); foxtail millet at Institute of Crop Science, Chinese Academy of Agricultural Sciences (ICS-CAAS) $(26,233)$; barnyard millet at Department of Genetic Resources I, National Institute of Agrobiological Sciences, Japan (3671); proso millet at N.I. Vavilov All-Russian Scientific Research Institute of Plant Industry (VIR) (8778); teff at Ethiopian Institute of Biodiversity, Ethiopia (5169); fonio at Laboratoire des Ressources Génétiques et Amélioration des Plantes Tropicales, ORSTOM, France (235); and job's tears at the Department of Genetic Resources I, National Institute of Agrobiological Sciences, Japan (151). Guinea millet accessions were present only at Centro Internacional de Agricultura Tropical (CIAT), Colombia (2) and International Livestock Research Institute (ILRI) Ethiopia (1), while 2087 accessions belong to the genus Brachiaria were conserved globally. Except for finger millet, foxtail

Table 2 Global status of cultivated, wild and weedy relatives of small millets germplasm conserved in genebanks

\begin{tabular}{|c|c|c|c|c|c|c|c|}
\hline S. no & Crop name & Africa & Asia & $\begin{array}{l}\text { United States of } \\
\text { Americas }\end{array}$ & Europe & Oceania & Total \\
\hline \multirow[t]{2}{*}{1} & Finger millet (Elusine coracana) & 6700 & 28,663 & 1456 & 36 & 18 & 36,873 \\
\hline & Other species of the genus Elusine & 1628 & 256 & 20 & 40 & 22 & 1966 \\
\hline \multirow[t]{2}{*}{2} & Foxtail millet (Setaria italica) & 166 & 38,572 & 1145 & 4548 & 330 & 44,761 \\
\hline & Other species of the genus Setaria & 976 & 209 & 341 & 372 & 9 & 1907 \\
\hline \multirow[t]{2}{*}{3} & $\begin{array}{l}\text { Barnyard millet (Echinochloa colona \& E. } \\
\text { crus-galli) }\end{array}$ & 59 & 7444 & 316 & 53 & 51 & 7923 \\
\hline & Other species of the genus Echinochloa & 248 & 371 & 71 & 8 & 9 & 707 \\
\hline 4 & Proso millet (Panicum miliaceum) & 11 & 12,110 & 1147 & 15,812 & 228 & 29,308 \\
\hline \multirow[t]{2}{*}{5} & Little millet (Panicum sumatrense) & 7 & 2830 & 226 & - & 1 & 3064 \\
\hline & Other species of the genus Panicum & 3853 & 9599 & 2161 & 677 & 142 & 16,432 \\
\hline \multirow[t]{2}{*}{6} & Kodo millet (Paspalum scrobiculatum) & 356 & 4043 & 354 & 14 & 13 & 4780 \\
\hline & Other species of the genus Paspalum & 357 & 190 & 2812 & 41 & 524 & 3924 \\
\hline \multirow[t]{2}{*}{7} & Teff (Eragrostis tef) & 5046 & 402 & 373 & 41 & 20 & 5882 \\
\hline & Other species of the genus Eragrostis & 1338 & 236 & 1281 & 253 & 77 & 3185 \\
\hline \multirow[t]{3}{*}{8} & White Fonio (Digitaria exilis) & 604 & 4 & 1 & 236 & 17 & 862 \\
\hline & Black fonio (Digitaria iburua) & & & 1 & & & 1 \\
\hline & Other species of the genus Digitaria & 712 & 542 & 798 & 56 & 367 & 2475 \\
\hline \multirow[t]{2}{*}{9} & Job's tears (Coix lacryma-jobi) & 3 & 288 & 26 & 40 & 4 & 361 \\
\hline & Other species of the genus Coix & & & & 2 & & 2 \\
\hline 10 & Guinea millet (Urochloa deflexa) & 1 & & 2 & & & 3 \\
\hline \multirow[t]{2}{*}{11} & Browntop millet (Urochloa ramosa) & 1 & 29 & & 1 & & 31 \\
\hline & Other species of the genus Urochloa & 675 & 73 & 1285 & 26 & 28 & \\
\hline Grand total & & 22,741 & 105,861 & 13,816 & 22,256 & 1860 & 164,447 \\
\hline
\end{tabular}

Source: http://www.fao.org/wiews-archive/germplasm_query.htm?i_l=EN, accessed in 29 Aug 2018 
millet and proso millet, germplasm conserved in genebanks globally are very low for other crops. This could be due to low research priority on those crops, and most landraces already been lost due to a shift from traditional crops and landraces to cash crops and improved varieties and hybrids. Therefore, collection and conservation of existing small millets' diversity is crucial before we lose them forever, particularly in fonio, job's tears, guinea millet, and browntop millet, where a very limited number of germplasm $(<1000)$ are conserved globally.

\section{Germplasm diversity representative subsets}

Germplasm diversity representative subsets such as core collection ( $10 \%$ of the entire collection) and mini core collection ( $\sim 1 \%$ of the entire collection and/or $\sim 10 \%$ of core collection) are the ideal starting point for using germplasm in crop improvement. Such subsets are available in most small millets (Table 3 ). These diversity representative sets could be effectively evaluated in multiple locations and years to identify and utilize promising trait-specific germplasm resources in crop improvement. Similar efforts are required in other small millets where such sets are not available, and when the size of the collection is considerably large, for example, in teff.

\section{Promising trait-specific germplasm resources}

Small millets germplasm contains significant variation for morpho-agronomic, quality and stress tolerance traits, and promising germplasm sources have been reported in most crops. In finger millet core collection, 15 accessions each for grain Fe (37.66-65.23 mg kg-1), Zn (22.46-25.33 mg kg-1), $\mathrm{Ca}\left(3.86-4.89 \mathrm{~g} \mathrm{~kg}^{-1}\right)$ and protein $(8.66-11.09 \%)$ contents were identified, and 24 of them were identified based on their superiority over control cultivars for two or more grain nutrients [166]. In foxtail millet core collection, 21 diverse promising accessions each for early maturity, higher grain yield, and higher grain nutrients (protein 15.6-18.5\%; Ca $171.2-288.7 \mathrm{mg} \mathrm{kg}^{-1}$; Fe 58.2-68.0 $\mathrm{mg} \mathrm{kg}^{-1}$; and $\mathrm{Zn}$ $54.5-74.2 \mathrm{mg} \mathrm{kg}^{-1}$ ) were identified [167]. In proso millet, germplasm for higher grain-yield (18 accessions), and greater seed weight ( 8 accessions) were reported [176]. For grain nutrients, 12 proso millet accessions were identified for $\mathrm{Fe}\left(63.3-73.2 \mathrm{mg} \mathrm{kg}^{-1}\right), 27$ accessions for $\mathrm{Zn}\left(40.6-46.7 \mathrm{mg} \mathrm{kg}^{-1}\right), 56$ accessions for $\mathrm{Ca}$ (185.5-241.2 $\mathrm{mg} \mathrm{kg}^{-1}$ ) and 27 for protein (16.1-19.1\%), of which 28 were rich in two or more grain nutrients, including IPm 2069, IPm 2076 and IPm 2537 for high Fe, Zn, Ca, and protein content [176]. In kodo millet, promising trait specific accessions for early maturity ( 8 accessions), greater seed weight (10), high grain yield (15), and higher grain nutrients [Fe (8), $\mathrm{Zn}(14), \mathrm{Ca}(6)$ and protein (7)] have been reported, of which 10 accessions (IPs 4, IPs 5, IPs 77, IPs 83, IPs 222, IPs 264, IPs 279, IPs 686, IPs 689, and IPs 814) were reported as promising for both agronomic and grain nutrient traits [177]. In little millet, 10 accessions for greater seed weight, 15 each for high grain yield and high biomass yield, and 30 for high grain nutrients have been identified, including 3 accessions for two or more nutrients (IPmr 449 for Fe, $\mathrm{Zn}, \mathrm{Ca}$ and protein; IPmr 981 for $\mathrm{Zn}$ and protein; and IPmr 977 for $\mathrm{Ca}$, and protein); and five accessions (IPmr 855, IPmr 974, IPmr 877, IPmr 897, and IPmr 767) that produced grain yield over $1500 \mathrm{~kg} \mathrm{ha}^{-1}$ (Vetriventhan, unpublished).

Blast in finger millet and foxtail millet; grain smut and sheath blight in little millet; head smut and blight in kodo millet; smut and leaf spot in barnyard millet; head smut, sheath blight and bacterial spot in proso millet; and rust in teff are important diseases. Germplasm sources for blast resistance in finger millet [12] and foxtail millet [155],
Table 3 Germplasm diversity representative subsets, core and mini core collections in small millets

\begin{tabular}{llllrl}
\hline Crop & Germplasm subsets & $\begin{array}{l}\text { No. of acces- } \\
\text { sions used }\end{array}$ & No. of traits & $\begin{array}{l}\text { No. of acces- } \\
\text { sions in subset }\end{array}$ & $\begin{array}{l}\text { Refer- } \\
\text { ences }\end{array}$ \\
\hline Finger millet & Core collection & 5940 & 14 & 622 & {$[164]$} \\
& Core collection & 4511 & 27 & 551 & {$[53]$} \\
& Core collection & 1000 & 23 & 77 & {$[61]$} \\
& Mini core collection & 622 & 20 & 80 & {$[168]$} \\
Foxtail millet & Core collection & 1474 & 23 & 155 & {$[165]$} \\
& Core collection & 1478 & 23 & 156 and 78 & {$[51]$} \\
Proso millet & Mini core collection & 155 & 21 & 35 & {$[167]$} \\
Barnyard millet & Core collection & 833 & 20 & 106 & {$[169]$} \\
& Core collection & 736 & 21 & 89 & {$[163]$} \\
Little millet & Core collection & 729 & 24 & 50 & {$[50]$} \\
& Core collection & 460 & 20 & 56 & {$[163]$} \\
Kodo millet & Core collection & 895 & 21 & 55 & {$[52]$} \\
\hline
\end{tabular}


salinity and drought tolerance in finger millet $[87,89]$ and foxtail millet $[86,88]$, have been reported. Ramakrishnan et al. [141] identified finger millet mini core accessions tolerant to low phosphorus stress; five (IE 5201, IE 2871, IE 7320, IE 2034, IE 3391) of them had high root and shoot length, root hair density, and root hair length. A limited number of resistant sources for major diseases, and to some extent, for pests in proso, barnyard, little and kodo millets have been reported [171, 175]. In teff, shoot fly is an important insect pests. Nigus [123] evaluated 49 teff germplasm, including 32 released varieties, 12 promising lines and local landraces for shoot fly resistance, and reported acc. $17 \mathrm{WJ}$ as resistant $(<5 \%$ damage), 10 accessions as moderately resistant (6-10\% damage), and others as susceptible ( $>11 \%$ damage).

\section{Small millets improvement}

\section{Production constraints and breeding targets}

Table 4 shows breeding target traits for each of small millets. In general, yield and parameters contributing to yield are the most targeted traits in small millets improvement. Therefore, selection for yield per se has been the major basis for improving productivity, but genotype $\times$ environment interactions highly influence these traits. Therefore, assessing yield stability across multiple environments and investigating physiological traits (such as harvest index, water use efficiency, etc.) associated with yield and adaptation are essential to target yield increase. Germplasm collections exhibit significant variation for various traits, including maturity duration [163-165, 169, 176, 177] that can be exploited to breed custom-made cultivars that fit into the different maturity groups: early, mid-late and late, depending on the location-specific requirements of soil, rainfall, temperature, humidity, day-length and cropping patterns. Short-duration varieties would be suitable for double/intensive cropping regions and medium-to long-duration varieties for single cropping season areas.

Small millets have high nutritional potential, while their utilization is limited by the presence of antinutrients such as phytate, phenols, tannins, and enzyme inhibitors, and also a high amount of protease and amylase inhibitors that affect the digestibility of millets grains [178]. Most grain nutrients in small millets are generally higher than the major cereals, however, large variability exists in germplasm, including for grain nutrients [166, 167, 176, 177] and antinutrients [130, 178]. Exploiting existing variability present in germplasm and hybridization-derived variations can support in breeding nutrients-dense cultivars in higher-yielding background.

Small millets are well adapted to diverse climatic conditions and are less affected by major biotic and abiotic stresses. However, a few diseases and insect pests are causing considerable yield loss, and therefore, breeding for cultivars resistant to diseases and pests is important. Blast is a very prominent disease in finger millet; yield losses of up to $88 \%$ have been reported $[119,143]$. Similarly, blast, rust and smut are the most severe diseases in foxtail millet [175]; sheath blight, bacterial spot and head smut in proso millet; grain and head smut and leaf spot diseases in barnyard millet, kodo millet and little millet [171], leaf rust in teff; and smut and leaf spot in job's tears. Proso millet, barnyard millet, little millet and kodo millet are mostly damaged by shoot fly, and finger millet and barnyard millet by stem borers [171].

Small millets are mostly grown as rainfed crops, and are considerably affected by drought due to the failure of monsoon. In addition to drought, lodging is major problem in all small millets, mainly due to their soft stalk, crop management and environmental factors [146, 171, 175]. There is no direct estimate of yield loss in small millets due to lodging,

Table 4 Targeted traits for improvement of small millets for increased yield, adaptation and quality

\begin{tabular}{ll}
\hline Crop & Trait focus \\
\hline Finger millet & Blast resistance, drought and salinity tolerance, machine harvestable, non-lodging, and bold grain size \\
Foxtail millet & $\begin{array}{c}\text { Blast and sheath blight resistance, non-lodging, bold grain size, and strong culm for mechanical } \\
\text { harvesting } \\
\text { Shoot fly and smut resistance, non-shattering, and non-lodging }\end{array}$ \\
Proso millet & Shoot fly resistance, non-lodging, and bold grain size \\
Little millet & Shoot fly, head smut and sheath blight resistance, non-lodging, nutrient-response and drought recovery \\
Kodo millet & Grain smut, sheath blight and shoot fly resistance, bold grain size, and non-shattering \\
Barnyard millet & Drought tolerance and lodging resistance, desirable grain quality, non-shattering, and bold grain size \\
Teff & Non-shattering, non-lodging, early maturity, and bold grain size \\
Fonio & Non-lodging, smut and leaf spot resistance \\
Job's tears & Non-lodging, non-shattering, and bold grain size \\
Guinea millet & Non-lodging, and non-shattering \\
Browntop millet &
\end{tabular}


but major cereals like rice and wheat have recorded up to $50 \%$ losses [161]. It occurs due to the bending of plants at maturity due to higher panicle weight, soft stalk and weak anchorage roots [162]. Lodging is genotype-dependent and influenced by the environment, therefore developing cultivars with improved lodging resistance is essential to minimize yield and quality losses. Another important trait for small millets is shattering [146]. Significant yield losses occur due to grain shattering in small millets, therefore shattering-resistant/tolerant small millets will be critical to prevent shattering-induced yield losses.

Special breeding traits to enhance the cultivation and consumption of small millets are developing machine harvestable cultivars, enhancing the nutritive value of grain and fodder to fetch high market value, developing cultivars suitable to make value-added products such as rice, flour, vermicelli, flakes, hot and cold extruded snacks, noodles and ready-tocook mixtures, shade-tolerant genotypes for orchards and agro-forestry, quick growing genotypes for inter-cropping and genotypes suitable for rice-fallows.

\section{Conventional breeding approaches}

Various breeding methods such as pure line selection, pedigree selection, mass selection, and mutation breeding, which are applicable to self-pollinating crops are followed in small millets as well. Reports on small millets cultivars released over a period of time shown that a majority of them were released following selection from local landraces/cultivars, followed by pedigree selection (hybridization and selection). For example, in India, of the 248 varieties of six small millets (finger millet-121, foxtail millet-32, proso millet -24 , kodo millet -33 , barnyard millet- 18 and little millet-20), about $65 \%$ were released following selection from landraces, about 30\% through pedigree selection, and 5\% through mutation breeding [3]. In the USA, 11 proso millet cultivars were released following selection from landraces and 8 following pedigree selection [146, 147].

Hybridization to create variability followed by selection in segregating population has been an important breeding method in small millets particularly in finger millet, foxtail millet and proso millet. In finger millet, $45 \%$ of the cultivars released in India were following hybridization and selection breeding method, while $22 \%$ in foxtail millet and $29 \%$ in proso millet [3]. However, small millets are not easily amenable to hybridization due to their floral morphology and anthesis behavior. Hybridization techniques available in small millets include contact method (panicles of selected plants are enclosed in a parchment bag before flowering to enhance the chances of natural crosspollination) and controlled hybridization either by hand emasculation or hot water emasculation. Hot water treatment of inflorescence (3-4 days of emergence) at $52{ }^{\circ} \mathrm{C}$ for
5 min found effective in inducing male sterility in finger millet, while $48{ }^{\circ} \mathrm{C}$ for $4-5$ min in barnyard millet [56]. Emasculation and crossing techniques have been reported in small millets [56, 96, 121, 158]. Understanding floral biology and pollination system helps in devising appropriate emasculation and crossing protocols [56]. However, the success rate of making the cross is generally very low, even for experienced hands, thereby limiting the number of genetic studies and yield improvement in small millets.

Exploitation of hybrid vigor is limited in small millets, due to difficulties in hybridization. Thus, developing male sterile lines would be a viable option to use heterosis, which is being successfully implemented in major crops for commercial hybrid seed production. So far, only one male sterile line has been reported in finger millet (INFM 95001), which has a GMS system developed from the source parental line IE 3318 (germplasm) through chemical mutation (EMS) [59]. In foxtail millet, several types of male sterile lines have been developed in China [180]. However, only partial genetic male sterile lines have been used successfully in hybrid seed production [42]. There are no reports on male-sterile lines in other small millets.

In general, mutation breeding has played a key role in self-pollinated crops where hybridization is very difficult to create variability. Mutation breeding has resulted in the release of 13 small millet cultivars (finger millet 8 , kodo millet 3, and little millet 2 ) in India. The use of chemical hybridizing agents (CHAs) to induce male sterility in small millets needs to be explored. The usefulness of mutagen depends on its mutagenic effectiveness (mutations per unit dose of mutagen) and efficiency (mutation in relation to undesirable changes/damage like sterility, lethality, injury etc.) in order to recover a high frequency and spectrum of desirable mutations. In finger millet, 500 Gray (Gy) and 600 Gy were found effective in the developing early-maturing mutant lines with high yield and yield component characters [5], and Muduli et al. [113] reported that the treatments with $0.30 \%$ and $0.45 \%$ EMS, $0.03 \%$ nitroso guanidine $(\mathrm{NG})$ and combination treatment of 300 Gy gamma ray $+0.30 \%$ EMS as more effective in inducing useful mutations. Bhave et al. [20] irradiated local cultivar of proso millet using gamma rays and identified two early-maturing mutants from $40 \mathrm{krad}$ and 50 krad doses, and two high-yielding mutants from $20 \mathrm{krad}$ and $60 \mathrm{krad}$ doses. In barnyard millet, $0.3 \%$ of EMS was identified as $\mathrm{LD}_{50}$ value and $500 \mathrm{~Gy}$ and $600 \mathrm{~Gy}$ of gamma irradiation create good variability (IIMR, unpublished). In kodo millet, a dose of $0.4 \%$ EMS was reported as suitable for optimum recovery of viable mutants [79]. In teff, Desta et al. [41] used $0.2 \%$ of EMS for $8 \mathrm{~h}$ and reported significant variability in the mutant population and identified candidate mutant lines that showed Al-tolerance. Induced mutation techniques are also being used in teff to generate 
variability for important traits such as lodging resistance given the lack of sufficient variability in the existing germplasm collection [9]. Animasaun et al. [6] reported that the most efficient treatment time in fonio for inducing variation was $0.1 \mathrm{M}$ nitrous acid for $4 \mathrm{~h}$ of exposure of seeds.

Conventional breeding approaches have been successful in characterizing small millets germplasm and their use in developing and releasing several cultivars, including for resistance/tolerance to biotic and abiotic stresses. Genomicsassisted improvement by utilizing various omics approaches can potentially contribute to enhanced genetic gains in small millets improvement.

\section{Genomic resources and genomics-assisted small millets improvement}

\section{Genome sequence}

Genome sequencing provides direct access into the coding and non-coding regions of the genome that regulates growth, development and response to environmental stimuli. Also, the sequence data facilitates the development of genome-scale markers that provide a greater understanding of diversity, structure, evolution, mapping sequence variation associated with traits of interest, and in developing molecular tools to use in genomics-assisted crop improvement. Versatile sequencing platforms have not only eased costs but also provide higher coverage, depth and reliability. In the case of small millets, genomes of foxtail millet, finger millet, proso millet, teff, and Japanese barnyard millet have been sequenced so far, and also complete chloroplast genome sequences of foxtail millet, proso millet, little millet and barnyard millet are available (Table 5). Foxtail millet has the smallest genome size $(423-510 \mathrm{Mb})$ while finger millet has the largest one $(1.5 \mathrm{~Gb})$ followed by barnyard millet (E. crus-galli, $1.27 \mathrm{~Gb}$ ). Foxtail millet was the first crop among millets to have its genome fully sequenced; it serves as a model for $\mathrm{C}_{4}$ crop species because of its small diploid genome, short duration and self-pollinating nature. Despite the use of next-generation platforms, most of the millet genomes are in the draft sequence stage and require resequencing and reannotation efforts to fill the gaps, mis-annotations and chromosomal assignments. However, the draft sequence information is adequately informative for largescale genotyping applications and gene mining. The ICRISAT in collaboration with Cornell University genotyped a diverse set of six small millets (finger millet, barnyard millet, foxtail millet, proso millet, kodo millet and little millet) through genotyping-by-sequencing (GBS) approach and identified genome-wide single nucleotide polymorphisms and assessed the population structure and diversity [81, 170, 179]. One of the bottlenecks in millets genome sequencing could be attributed to the ploidy levels and higher proportion of repetitive DNA. However, the emergence of third-generation sequencing systems coupled with high-throughput data

Table 5 Nuclear and chloroplast genome sequence resources of small millets

\begin{tabular}{|c|c|c|c|c|c|c|}
\hline Crop & Scientific name & Genotype name & Genome size & No. of gene(s) & Sequence type & References \\
\hline \multicolumn{7}{|c|}{ Nuclear genome sequence } \\
\hline \multirow[t]{2}{*}{ Foxtail millet } & Setaria italica & Yugu1 & $510 \mathrm{Mb}$ & $24,000-29,000$ & Reference genome & {$[17]$} \\
\hline & S. italica & Zhang gu & $423 \mathrm{Mb}$ & 38,801 & Draft genome & [194] \\
\hline \multirow[t]{2}{*}{ Finger millet } & Elusine coracana & ML-365 & $1196 \mathrm{Mb}$ & 85,243 & Draft genome & {$[70]$} \\
\hline & & PR202 & $1500 \mathrm{Mb}$ & 62,348 & Draft genome & {$[65]$} \\
\hline \multirow[t]{2}{*}{ Proso millet } & Panicum miliaceum & $\begin{array}{l}\text { Landrace (Accession } \\
\text { Number 00000390) }\end{array}$ & $923 \mathrm{Mb}$ & 55,930 & Draft genome & [196] \\
\hline & P. miliaceum & Longmi4 & $887.8 \mathrm{Mb}$ & 63,671 & Draft genome & {$[156]$} \\
\hline Teff & Eragrostis tef & Tsedey (DZ-Cr-37) & $672 \mathrm{Mb}$ & 28,113 & Draft genome & {$[23]$} \\
\hline Barnyard millet & Echinochloa crus-galli & STB08 & $1.27 \mathrm{~Gb}$ & 108,771 & Draft genome & {$[55]$} \\
\hline \multicolumn{7}{|c|}{ Chloroplast genome } \\
\hline Foxtail millet & S. italica & - & 135,516 bp & 111 & - & {$[157]$} \\
\hline \multirow[t]{2}{*}{ Proso millet } & P. miliaceum & - & 139,929 bp & 132 & - & {$[25]$} \\
\hline & P. miliaceum & - & $139,826 \mathrm{bp}$ & 108 & - & {$[122]$} \\
\hline Little millet & P. sumatrense & Accession No. IT261894 & $139,384 \mathrm{bp}$ & 125 & - & {$[151]$} \\
\hline \multirow[t]{3}{*}{ Barnyard millet } & $\begin{array}{l}\text { Echinochloa esculenta } \\
\quad(=\text { E. crus-galli ssp. } \\
\text { utilis })\end{array}$ & Accession No. IT230633 & $139,851 \mathrm{bp}$ & 111 & - & {$[152]$} \\
\hline & E. crus-galli & BTS02 & $139,800 \mathrm{bp}$ & & - & {$[190]$} \\
\hline & E. frumentacea & $\mathrm{CO}(\mathrm{KV}) 2$ & $139,593 \mathrm{bp}$ & 112 & - & {$[133]$} \\
\hline
\end{tabular}

- Data not available or not applicable 
analysis platforms are expected to resolve these bottlenecks in due course of time.

\section{Gene mapping}

Prior to the emergence of genome sequence approaches, genes and genomic regions regulating traits of interest were mapped in millets using low-throughput markers, including RAPD, RFLP, AFLP and SSRs. In foxtail millet, Wang et al. [184] were the first to construct an RFLPbased map to identify that chromosome 8 carries a gene that strongly affects gamete fertility. The RAPD and ISSRbased germplasm characterization was reported in finger millet by Gupta et al. [58]; however, the first genetic map spanning $721 \mathrm{cM}$ on the A genome and $787 \mathrm{cM}$ on the B genome was constructed by Dida et al. [44] using a combination of RFLP, AFLP and SSR markers. In addition, DNA markers (SSR, EST-SSR, ILP and microRNA-based molecular markers) developed using foxtail millet genome sequence information showed higher $(>85 \%)$ cross-genera transferability among other millets, including proso millet, barnyard millet, little millet and kodo millet, as well as non-millet species [90, 129, 186], and approximately $62 \%$ of switchgrass SSR markers were transferable to proso millet [139]. These higher percentage of crosstransferability demonstrate the potential of these markers in germplasm characterization, marker-trait association and marker-assisted breeding in other millets for which no genomic resources are available. In well researched crops like foxtail millet and finger millet, next-gen approaches, including GBS have been used to pinpoint quantitative trait nucleotides (QTNs) associated with traits of interest. Jia et al. [80] constructed a high-density haplotype map in foxtail millet using $\sim 1$ million SNPs and identified 512 loci associated with forty-seven agronomic traits. Following this, Jaiswal et al. [75, 76] identified SNPs associated with ten yield-contributing agronomic traits as well as micronutrients in foxtail millet. Sharma et al. [153] and Rajput et al. [140] in proso millet identified SNP markers associated with important agro-morphological traits.

In addition to mapping, direct identification of genes has been made possible through advancements in whole genome sequencing. The availability of genome sequences in public databases (like Phytozome, Gramene and GenBank) had enabled the identification of genes and gene families in sequenced genomes followed by their functional characterization [118]. Foxtail millet being the first millet to be sequenced had evidenced a large number of reports on identification and characterization of gene families, including $N A C$ [134], WD40 [111], AP2/ $E R F$ [91], $C_{2} H_{2}$ zinc finger [115], $M Y B$ [116], DCL, AGO, RDR [187], WRKY [114], LecRLK [195], ADP-ribosylation factors [117], ATG [101], heat shock proteins and factors [160], CDPK [191] and LIM genes [188]. In the wild ancestor, S. viridis, [31] has identified and validated the phosphate transporter gene family.

\section{Other omics approaches for gene discovery and crop improvement}

\section{Transcriptomics}

Although genetics and genomics have made significant progress in studying millets, other omics approaches are relatively new to these crops, and not much of reports are available on the use of other omics tools to study the millets. Transcriptome-based gene expression profiling is a functional genomic approach for characterizing the candidate genes regulating various biological processes, and provides comprehensive information about expression pattern of genes and functional polymorphism [82]. In this aspect, foxtail millet transcriptome was the first to be released, where Zhang et al. [194] had sequenced the total RNA of root, stem, leaf and spike of the strain 'Zhang gu'. Recently, Li et al. [99] had sequenced the transcriptome of foxtail millet during Sclerospora graminicola infection, and identified several candidate genes for further functional characterization. Notably, the study pinpointed an amidase encoding gene, Seita.2G313400, that showed 30 -fold upregulation during the infection. In finger millet, Rahman et al. [136] analyzed the salinity responsive leaf transcriptome of contrasting finger millet genotypes and identified several differentially expressed genes in the tolerant genotype. Hittalmani et al. [70] had sequenced the transcriptome of finger millet variety ML-365 under well-watered and low moisture stress treatments. The study identified 12,893 unigenes specifically expressed in low moisture stress. Following this study, Akbar et al. [4] had performed RNA-seq of developing spikes to dissect the oxalic acid biosynthesis pathway in finger millet. The data concluded that ascorbate-tartrate pathway could be a predominant player in oxalic acid biosynthesis, and this could be useful in studying the nutrients-antinutrients interactions in this crop. Parvathi et al. [132] had analyzed the transcriptome dynamics in the leaf samples of finger millet exposed to drought stress. The study highlighted two candidate genes, CIPK31 and TAF6, that could be studied further to delineate their roles in conferring drought tolerance. In proso millet, RNA-seq data was first reported by Yue et al. [193], which served as an excellent sequence resource for gene discovery and marker development in this crop. Few reports also available in other millets, including barnyard millet for drought tolerance, and $\mathrm{Fe}$ and $\mathrm{Zn}$ accumulation [77], submergence tolerance [120]; and in teff for waterlogging [24], to understand the 
gene regulatory mechanisms in these crops. These studies underline the application of transcriptomics in identifying the gene repertoire underlying the traits-of-study, which can then be further characterized and used in crop improvement.

\section{Proteomics and metabolomics}

As transcript abundance and expression does not directly correlate with the protein/metabolome levels, and in order to study the post-translational modifications that proteins/ metabolomes undergo to perform any given function, proteomics and metabolomics studies gain importance. For example, in finger millet, Singh et al. [159] characterized the calcium binding proteins (CaBPs) in grain filling stages using proteomics approach and reported that the higher synthesis of $\mathrm{CaBP}$ during later stages of grain filling might be responsible for the sequestration of calcium in endoplasmic reticulum of finger millet. In foxtail millet, $\mathrm{Li}$ et al. [98] investigated proteomic changes in the grains under drought stress and salinity, and identified 104 differently expressed proteins, while Veeranagamallaiah et al. [174] performed proteomic analysis of 7-days old salt-treated tolerant cv. 'Prasad' seedlings and identified 29 differentially expressed proteins involved in signal transduction, photosynthesis, metabolism and stress response. In metabolomics aspect, De Oliveira Dal'Molin [35] was the first to perform metabolic reconstruction and multiple omics mapping using transcriptome, proteome, and targeted metabolome data of foxtail millet. The study identified significant abundance of metabolites that play roles in $\mathrm{C}_{4}$ metabolism, which underlines the potential of foxtail millet as a $\mathrm{C}_{4}$ model. Similarly, Li et al. [100] studied the qualitative and quantitative differences in both the primary and secondary metabolites in six foxtail millet varieties using LC-MS analysis. The study not only defined the specific accumulation of metabolites, but also provided insights into metabolome engineering to develop trait-specific metabolites. Recently, Agtuca et al. [2] reported the metabolomic changes in the roots during colonization of endophytic bacteria in $S$. viridis, the wild progenitor of foxtail millet. The study highlighted how the endophytic plant growth-promoting bacteria modulates host metabolic pathways to enhance the growth, development and defense response of $S$. viridis. At this point-of-time, metabolomics has not been extended to other millets, and in light of these experiments reported in foxtail millet, it is expected to gain momentum in other related crops.

\section{Genetic transformation of small millets}

Agrobacterium-mediated system has been predominantly used in small millets transformation. However, compared to other major cereals like rice, genetic transformation studies in millets are lagging [29]. Reports on optimization of transformation protocols and transgenic plants expressing functionally active transgenes in millets are of recent origin. Details on genetic transformation studies reported in small millets are presented in Table 6 . There are substantial number of reports on finger millet and foxtail millet on genetic transformation. The first finger millet transformation study was reported by Gupta et al. [57], whose preliminary work used biolistic method to compare the efficiency of five gene promoters for the expression of GUS reporter gene. Later, several studies in finger millet focused on development of transgenics for leaf blast resistance [73, 92], drought and salinity tolerance [66], herbicide resistance [15], and improved zinc concentration [142]. In foxtail millet, Agrobacterium-mediated transformation was first reported by Liu et al. [106]. Later studies have focused on developing transgenic foxtail millet tolerant to drought and salinity [94, 97, 127, 181], and characterization of phosphate transport [26]. While only a few studies on the genetic transformation are available on barnyard millet, teff, and fonio and none are available on little millet, proso millet and kodo millet. There is one report each on barnyard millet, fonio and teff. In barnyard millet, an old report is available on biolistic transformation for testing the efficiency of various promoters in GUS expression [57]. Since then, no effort has been made to transform barnyard millet using Agrobacterium-mediated system. Teff was transformed by Agrobacterium with runner bean (Phaseolus coccineus) gibberellin inactivation (PcGA2oxl) gene [48] to study its function on growth. Embryogenic callus derived from immature embryos was used as explants for transformation. In vitro regeneration protocol was reported in proso millet [62], kodo millet [28, 84, 85], little millet [112], and barnyard millet [137, 138], that could enable transgenic work to be explored in order to introduce key genes to confer resistance against various stresses.

The availability of optimized protocols for genetic transformation has seen the application of transgene-based approach in a few small millets. However, this is yet to be standardized in several millets; until then, manipulating genes directly to overexpress, knock-out/down, or using CRISPR/Cas9 system will not be feasible. Genome editing systems like CRISPR/Cas9 have been frequently used in other major cereals like rice for functional genomics and crop improvement studies [30]. The use of CRISPR/Cas9 mutagenesis was reported in foxtail millet [104], where mutation of foxtail millet $P D S$ gene by CRISPR/Cas9 system has been achieved through protoplast transfection. Several genes with roles in enhancing yield-contributing agronomic traits, disease resistance, stress tolerance, and other desirable factors were identified in small millets but await comprehensive functional characterization 
Table 6 Details on genetic transformation studies reported in small millets

\begin{tabular}{|c|c|c|c|c|c|c|c|}
\hline $\begin{array}{l}\text { Name of the } \\
\text { millet }\end{array}$ & $\begin{array}{l}\text { Method of trans- } \\
\text { formation }\end{array}$ & $\begin{array}{l}\text { Name of the } \\
\text { genotype(s) used }\end{array}$ & $\begin{array}{l}\text { Type of explant } \\
\text { used }\end{array}$ & $\begin{array}{l}\text { Functional gene } \\
\text { used }\end{array}$ & $\begin{array}{l}\text { Frequency of } \\
\text { transformation } \\
(\%)\end{array}$ & Application & References \\
\hline \multirow[t]{13}{*}{ Finger millet } & \multirow[t]{9}{*}{$\begin{array}{l}\text { Agrobacterium- } \\
\text { mediated }\end{array}$} & PR 202 & $\begin{array}{l}\text { Embryogenic } \\
\text { seed }\end{array}$ & - & $44.4 \%$ & $\begin{array}{l}\text { Optimization of } \\
\text { transformation } \\
\text { protocol }\end{array}$ & [154] \\
\hline & & $\begin{array}{r}\text { GPU } 45 \text { and } \\
\text { Co(Ra) } 14\end{array}$ & Shoot apex & - & $3.8 \%$ & $\begin{array}{l}\text { Optimization of } \\
\text { transformation } \\
\text { protocol }\end{array}$ & [27] \\
\hline & & GPU 45 & Shoot apex & $\begin{array}{r}\text { Rice chitinase } \\
(\text { chi11) gene }\end{array}$ & $3.5-3.9 \%$ & $\begin{array}{l}\text { Leaf blast resist- } \\
\text { ance }\end{array}$ & {$[73]$} \\
\hline & & GPU 28 & $\begin{array}{l}\text { Callus and } \\
\text { embryogenic } \\
\text { callus }\end{array}$ & $O s Z I P 1$ & - & $\begin{array}{l}\text { Improvement of } \\
\text { seed } \mathrm{Zn} \text { con- } \\
\text { centration }\end{array}$ & [142] \\
\hline & & $\begin{array}{l}\text { Tropikanka and } \\
\text { Yaroslav } 8\end{array}$ & $\begin{array}{l}\text { Embryogenic } \\
\text { callus }\end{array}$ & $\begin{array}{l}H v T U B 1 \text { and } \\
\text { TUAm1 }\end{array}$ & $1.5 \%$ & $\begin{array}{l}\text { Resistance to } \\
\text { herbicide }\end{array}$ & [15] \\
\hline & & GPU 28 & $\begin{array}{l}\text { Embryogenic } \\
\text { callus }\end{array}$ & $\begin{array}{l}\text { Bacterial } m t l D \\
\text { gene }\end{array}$ & $7.5 \%$ & $\begin{array}{l}\text { Multiple stress } \\
\text { resistance }\end{array}$ & {$[66]$} \\
\hline & & GPU 28 & $\begin{array}{l}\text { Callus and } \\
\text { embryogenic } \\
\text { callus }\end{array}$ & $\begin{array}{l}P g N H X 1 \text { and } \\
A V P 1\end{array}$ & - & $\begin{array}{l}\text { Salinity toler- } \\
\text { ance }\end{array}$ & [78] \\
\hline & & ML 181 & Callus & SbVPPase & - & $\begin{array}{l}\text { Salinity toler- } \\
\text { ance }\end{array}$ & [7] \\
\hline & & $\begin{array}{l}\mathrm{CO}(\mathrm{Ra}) 14, \\
\text { PR 202, Try } 1 \\
\text { and Paiyur } 2\end{array}$ & Shoot apex & - & $11.8 \%$ & $\begin{array}{l}\text { Optimization of } \\
\text { transformation } \\
\text { protocol }\end{array}$ & [149] \\
\hline & \multirow[t]{4}{*}{ Biolistic } & PR 202 & Leaf sheath & - & - & $\begin{array}{l}\text { Testing the effi- } \\
\text { ciency of vari- } \\
\text { ous promoters }\end{array}$ & {$[57]$} \\
\hline & & $\begin{array}{l}\text { Local cultivar } \\
\text { PGEC } 2 \text { and } 19 \\
\text { accessions }\end{array}$ & Shoot apex & $\begin{array}{l}\text { Antifungal } \\
\text { protein (PIN) } \\
\text { of prawn }\end{array}$ & - & $\begin{array}{l}\text { Leaf blast resist- } \\
\text { ance }\end{array}$ & [92] \\
\hline & & PGEC 2 & $\begin{array}{l}\text { Shoot tip-embry- } \\
\text { ogenic callus }\end{array}$ & $P c S r p$ & - & $\begin{array}{l}\text { Salinity toler- } \\
\text { ance }\end{array}$ & [109] \\
\hline & & PR 202 & $\begin{array}{l}\text { Green nodular } \\
\text { calli }\end{array}$ & - & - & $\begin{array}{l}\text { Optimization of } \\
\text { transformation } \\
\text { protocol }\end{array}$ & [74] \\
\hline \multirow[t]{6}{*}{ Foxtail millet } & \multirow[t]{6}{*}{$\begin{array}{l}\text { Agrobacterium- } \\
\text { mediated }\end{array}$} & - & Callus & - & $6.6 \%$ & $\begin{array}{l}\text { Optimization of } \\
\text { transformation } \\
\text { protocol }\end{array}$ & [106] \\
\hline & & cv. Jigu11 & Callus & Si401 & - & $\begin{array}{l}\text { Regulation of } \\
\text { anther develop- } \\
\text { ment }\end{array}$ & [135] \\
\hline & & cv. Jigu11 & Callus & $S B g L R$ & $90.72 \%$ & $\begin{array}{l}\text { Optimization of } \\
\text { transformation } \\
\text { protocol }\end{array}$ & [182] \\
\hline & & $\begin{array}{l}\text { Jigu11 and } \\
\text { Yugu2 }\end{array}$ & Callus & - & - & $\begin{array}{l}\text { Optimization of } \\
\text { transformation } \\
\text { conditions }\end{array}$ & [192] \\
\hline & & cv. Jigu11 & Callus & SiLEA14 & - & $\begin{array}{l}\text { Drought and } \\
\text { salinity toler- } \\
\text { ance }\end{array}$ & [182] \\
\hline & & cv. Jigu11 & Callus & SiARDP & - & $\begin{array}{l}\text { Drought toler- } \\
\text { ance }\end{array}$ & [94] \\
\hline
\end{tabular}


Table 6 (continued)

\begin{tabular}{|c|c|c|c|c|c|c|c|}
\hline $\begin{array}{l}\text { Name of the } \\
\text { millet }\end{array}$ & $\begin{array}{l}\text { Method of trans- } \\
\text { formation }\end{array}$ & $\begin{array}{l}\text { Name of the } \\
\text { genotype(s) used }\end{array}$ & $\begin{array}{l}\text { Type of explant } \\
\text { used }\end{array}$ & $\begin{array}{l}\text { Functional gene } \\
\text { used }\end{array}$ & $\begin{array}{l}\text { Frequency of } \\
\text { transformation } \\
(\%)\end{array}$ & Application & References \\
\hline & & cv. Jigu11 & Callus & - & - & $\begin{array}{l}\text { Characterization } \\
\text { of seed specific } \\
\text { promoter } \\
\text { pF128 }\end{array}$ & [128] \\
\hline & & cv. Jigu11 & Callus & SiLTP & - & $\begin{array}{l}\text { Drought and } \\
\text { salinity toler- } \\
\text { ance }\end{array}$ & [127] \\
\hline & & Maxima & Shoot apex & $\begin{array}{l}\text { SiPHT1;1,2 } \\
\text { and } 3\end{array}$ & $10 \%$ & $\begin{array}{l}\text { Characterization } \\
\text { of phosphate } \\
\text { transport }\end{array}$ & {$[26]$} \\
\hline & & cv. Jigu11 & Callus & SiASRP4 & - & $\begin{array}{l}\text { Drought and } \\
\text { salinity toler- } \\
\text { ance }\end{array}$ & [97] \\
\hline & Biolistic & var. 3661 & Florets & SiPf40 & - & $\begin{array}{l}\text { Functional char- } \\
\text { acterization of } \\
\text { SiPf4 gene }\end{array}$ & [105] \\
\hline Barnyard millet & Biolistic method & VL 29 & Callus & - & - & $\begin{array}{l}\text { Testing the effi- } \\
\text { ciency of vari- } \\
\text { ous promoters }\end{array}$ & {$[57]$} \\
\hline Teff & $\begin{array}{l}\text { Agrobacterium- } \\
\text { mediated }\end{array}$ & cv. DZ-01-196 & Callus & PcGA2ox & - & $\begin{array}{l}\text { Inducing semi- } \\
\text { dwarfism }\end{array}$ & [48] \\
\hline Fonio & $\begin{array}{l}\text { Agrobacterium- } \\
\text { mediated }\end{array}$ & $\begin{array}{l}\text { Agyong and } \\
\text { Churiwe }\end{array}$ & Callus & - & $2.1-2.7 \%$ & $\begin{array}{l}\text { Testing the effi- } \\
\text { ciency of vari- } \\
\text { ous promoters }\end{array}$ & [126] \\
\hline
\end{tabular}

SiPHT1, Setaria italica phosphate transporter 1; SiLEA14, Setaria italica late embryogenesis abundant 14; SBgLR, lysine-rich protein from potato; SiLTP, Setaria italica lipid transfer proteins; $m t l D$, mannitol-1-phosphate dehydrogenase; SbVPPase, vacuolar H+-pyrophosphatase gene from Sorghum bicolor; HvTUB1, Hordeum vulgare $\beta 1$-tubulin; TUAm1, mutant $\alpha 1$-tubulin; PgNHX1, Pennisetum glaucum sodium hydrogen exchanger1, AVP1, Arabidopsis vacuolar pyrophosphatase1; OsZIP1, Oryza sativa zinc-regulated iron-regulated like protein; SiARDP, Dehydration-responsive element binding protein; SiASRP Abscisic acid-, stress-, and ripening-induced proteins; SiPf40, Setaria italica ZIP-like gene; PcGA2ox, Phaseolus coccineus gibberellin inactivation gene; PcSrp, Porteresia coarctata serine-rich-protein

using genomics tools. However, the lack of an efficient transformation system is a bottleneck, which if resolved, could lead to functional studies on individual genes in small millets enabling a study of their roles in related crops like rice, wheat and sorghum using transgene-based approaches.

\section{Global status of small millets improvement}

In India, seven small millets (finger millet, foxtail millet, proso millet, barnyard millet, kodo millet, little millet, and browntop millet) are being cultivated. The All India Coordinated Research Project on Small Millets (AICRP-Small Millets) carries out this research in India, through a network of 14 centers located in State Agricultural Universities, ICAR institutes and 21 voluntary centers. Crop improvement through AICRP-Small Millets resulted in the development of high yielding varieties with resistance to blast disease, quality fodder, early and medium maturity and white seed in finger millet; resistance to head smut in kodo millet and resistance to shoot fly in proso millet and little millet. So far, a total of 248 varieties of these small millets have been released in India (AICSMIP, 2014; http://www.aicrpsm.res. in/). Among the cultivars released in India, selection from eight ICRISAT germplasm accessions were released as cultivars (Table 7). Currently, recombination breeding has been the approach used, especially in finger millet, resulting in the development of diverse and high grain yielding cultivars in India. It has also been used in foxtail millet, proso millet and barnyard millet. Finger millet varieties yield up to 5-6 t $\mathrm{ha}^{-1}$, and cultivars of other small millets yield up to $2.5-3 \mathrm{t}$ $\mathrm{ha}^{-1}$ under optimum management conditions.

In African, particularly in eastern and southern Africa, finger millet is an important food crop. However, systematic breeding efforts are very limited. A majority of the cultivars grown in Africa are either landraces or direct introductions. The ICRISAT-HOPE project in collaboration with the Department of Research and Development (DRD), Tanzania, released cultivars such as P 224 and U 15 in Tanzania, and 
the same cultivars were also released in Kenya and Uganda (http://hope.icrisat.org/new-varieties-promise-an-incre ase-in-tanzanias-finger-millet-production/). Selection from three ICRISAT's finger millet accessions were released as cultivars in Zambia (2) and Kenya (1) (Table 7). Teff is an important crop in Ethiopia in terms of area, production and consumption. Teff breeding in Ethiopia is coordinated by Debre Zeit Agricultural Research Center (DAZRC) of the Ethiopian Agricultural Research Institute (EIAR). About 42 teff varieties have been released in Ethiopia largely through direct selection from landraces and intraspecific hybridization of lines selected from the germplasm with yields of $1.4-3.6 \mathrm{t} \mathrm{ha}^{-1}[110]$.

In China, foxtail millet and proso millet are the most widely grown small millets. Cultivars released in the 1950s and 1960s were largely with simple grain yield comparisons among landraces, while hybridization-based pedigree selection gained popularity after the 1970 s. About 870 cultivars have been released since 1950 . Heterosis breeding in foxtail millet began in the 1960s with the development of male sterile lines by various approaches to develop hybrid cultivars. For example, a high yielding hybrid cultivar Zhangzagu 5 was released by Zhangjiakou Academy of Agricultural Sciences, Hebei Province, China, and yielded 12,159 kg/ha versus conventional cultivars whose yields ranged from 4500 to $6000 \mathrm{~kg} / \mathrm{ha}$ in 2007 [107]. The development of herbicideresistant foxtail millet cultivars has made the exploitation of heterosis a reality through the use of herbicide-resistant varieties as restorer lines [43]. Proso millet is a relatively minor crop compared to foxtail millet in China. Pure line selection and hybridization-based pedigree selection are the main methods of proso millet breeding. So far, there is no efficient method for emasculating this plant; so only a few cultivars have been developed through hybridization-based breeding and progress in proso millet breeding is rather slow. About 162 cultivars have been released since the 1950s, and among which the most popular ones currently grown in China include Yumi 2, Ningmi 14, Longmi 10, Neimi 5, Jinshu 8 and Longshu 23 [43]. Job's tears is also grown on limited acreage in China, and cultivars grown were mostly landraces with an average yield of about $3.21 \mathrm{t} \mathrm{ha}^{-1}$. Only a few institutes in Guizhou and Yunnan provinces are having breeding programs dedicated to this crop [43].

In the United States, proso millet and foxtail millet are most widely grown millets. Grains of these crops are largely used for birdfeed and in cattle-fattening rations. A focused breeding program to improve proso millet productivity started in 1965 under the alternative crops breeding program at Panhandle Research and Extension Centre (PHREC). This led to the release of several cultivars such as Sunup, Dawn, Cerise, Rise, Early bird, Hutsman, Sunrise, Horizon, and Plateau, which resulted in significant improvement in proso millet productivity. In the USA, 18 cultivars of proso millet are available to growers, 10 of which are landraces while remaining 8 are developed through hybridization [60, 146, 147]. Foxtail millet is cultivated as a catch crop, especially
Table 7 List of varieties released in small millets through selection from ICRISAT germplasm

\begin{tabular}{|c|c|c|c|c|}
\hline $\begin{array}{l}\text { Crop/accession } \\
\text { number }\end{array}$ & Country of origin & Country of release & Release name & Year released \\
\hline \multicolumn{5}{|l|}{ Barnyard millet } \\
\hline IEc 542 & Japan & India & PRJ 1 & 2003 \\
\hline \multicolumn{5}{|l|}{ Finger millet } \\
\hline IE 723 & & India & BM 1 & 1985 \\
\hline IE 2947 & Malawi & Zambia & FMV 287 & 1987 \\
\hline IE 4115 & Uganda & Kenya & KAK-WIMBI 2 & 2016 \\
\hline IE 2929 & Malawi & Zambia & Lima & 1987 \\
\hline IE 1010 & Unknown & Uganda & NAROMIL 1 & 2018 \\
\hline IE 882 & & Uganda & NAROMIL 2 & 2018 \\
\hline IE 2440 & Kenya & Uganda & NAROMIL 5 & 2018 \\
\hline IE 524 & & India & VL 101 & 1978 \\
\hline \multicolumn{5}{|l|}{ Foxtail millet } \\
\hline ISe 377 & India & India & Chitra & 1982 \\
\hline ISe 279 & India & India & SIC 3 (K 548-79) & 1985 \\
\hline \multicolumn{5}{|l|}{ Kodo millet } \\
\hline IPs 19 & India & India & GK 1 & 1977 \\
\hline IPs 115 & India & India & PSC 1 & 1986 \\
\hline IPs 85 & India & India & TNAU 86 & 2012 \\
\hline \multicolumn{5}{|l|}{ Proso millet } \\
\hline IPm 2769 & Ukraine & India & DHP 2769 & 2018 \\
\hline
\end{tabular}


for fodder and pet food for caged and wild birds. Nearly all foxtail millet cultivars grown in the USA are the result of selections from landraces. Several advanced lines that are resistant to wheat streak mosaic virus have been developed through hybridization [13].

\section{Promotion of small millets for better nutrition}

Cultivation and consumption of small millets can be promoted by (1) supporting production and improving productivity (through research and developments to enhance yield and nutritional qualities, cultivation as pure crops as well as intercrop with other main crops, cultivation as fail-safe crops - late sowing when monsoon fails, particularly early-maturing cultivars that yield considerably even under constrained environments); (2) providing on-farm support and linking farmers to value chains; (3) undertaking campaigns to build consumer awareness; (4) ensuring products in demand are available and accessible; (5) supporting processors, food service, health/medical and industrial sectors to incorporate millets (for example, development of modern readyto-eat and ready-to-cook products, post-harvest processing technology development, nutrition investigation, methods for extending shelf life, etc.); and (6) policy support (including small millets and value-added products in the public distribution systems, minimum support price and mid-day meal/school feeding schemes, etc.). The global Smart Food initiative, led by Africa and Asia with an executive council composed of FARA, CORAF, FANRPAN, APAARI and ICRISAT; and in India, the National Food Security Mission of the Government a Sub-mission on Nutri-cereals, are the great initiatives for millets promotion, consumption, demand creation, post-harvest value-addition and ultimately doubling farm level economy. In India, the year 2018 was celebrated as the National Year of Millets, and the FAO has endorsed India's proposal to declare 2023 as the International Year of Millets, to be submitted to the UN General Assembly, that show the significance of millets in a global prospective.

\section{Future challenges and prospects}

Small millets have the potential to serve as an alternate/ supplement to major cereal staples because of their ability to be used/cooked in similar ways, diverse adaptation to adverse conditions and nutritional qualities. Small millets can fit very well into multiple cropping systems both under irrigated and rainfed conditions. Their storability under normal storage conditions has made them 'famine reserves'. They can provide nutritious grains as well as valuable fodder in a short span of time. A very low number of germplasm and inadequate information on genetic diversity limits their effective utilization in crop improvement programs. Therefore, prioritizing germplasm collection is key to identifying trait specific resources, genes and alleles, which can be utilized in small millets breeding programs. So far, small millets varieties have been developed mainly through conventional breeding methods. The yield barrier in small millets can be broken by a male sterility system and exploiting heterosis, and genomics-assisted crop improvement, together with better crop management and mechanization. Genomicsassisted breeding will facilitate the identification of novel alleles and genes with superior agronomic performance and resistance to biotic and abiotic stresses to accelerate small millets improvement. Biotechnology techniques such as tissue culture and genetic engineering reported in related crops could potentially support small millets improvement. The rapid development of sequencing technologies can generate millions of sequence reads at a low cost and in a short time irrespective of whether there is prior sequence information or not. Next generation sequencing techniques enable the molecular characterization of an entire set of small millets germplasm. These techniques could be used in crops such as little millet, kodo millet, and job's tears where genome decoding has not yet been done. Similarly, comparative genomics facilitates the exploration of orthologous genes of important traits in less studied crops with available genome sequence information from rice and foxtail millet. The emergence of genome editing techniques allows the modification of the genome of small millets to enhance production and stress tolerance. In addition to conventional breeding and genomics-assisted improvement, a comprehensive and coordinated transdisciplinary collaboration across the agronomy, biomedical, food science and technology areas is required in order to shift the status of small millets out of 'minor and underutilized' crops' group. Additionally, public-private partnerships, public awareness, farmers' engagement across the countries who are interested in small millets research and promotion will be needed to incorporate small millets-based food products as an important source of nutrients in diets. Given the changing climate scenario and prevailing hidden hunger, greater research and developmental focus on small millets (and other traditionally important crops) is the key to achieve food, feed and nutrition security.

Open Access This article is licensed under a Creative Commons Attribution 4.0 International License, which permits use, sharing, adaptation, distribution and reproduction in any medium or format, as long as you give appropriate credit to the original author(s) and the source, provide a link to the Creative Commons licence, and indicate if changes were made. The images or other third party material in this article are included in the article's Creative Commons licence, unless indicated otherwise in a credit line to the material. If material is not included in the article's Creative Commons licence and your intended use is not permitted by statutory regulation or exceeds the permitted use, you will 
need to obtain permission directly from the copyright holder. To view a copy of this licence, visit http://creativecommons.org/licenses/by/4.0/.

\section{References}

1. Adoukonou-Sagbadja H, Schubert V, Dansi A, Jovtchev G, Meister A, Pistrick K, et al. Flow cytometric analysis reveals different nuclear DNA contents in cultivated Fonio (Digitaria spp.) and some wild relatives from West-Africa. Plant Syst Evol. 2007;267:163-76.

2. Agtuca BJ, Stopka SA, Tuleski TR, Do Amaral FP, Evans S, Liu Y, et al. In-situ metabolomic analysis of Setaria viridis roots colonized by beneficial endophytic bacteria. Mol Plant-Microbe Interact. 2020;33:272-83.

3. AICSMIP. Report on compendium of released varieties in small millets [Internet]. Banglore, India; 2014. http://www.dhan.org/ smallmillets/docs/report/Compendium_of_Released_Varieties_ in_Small_millets.pdf. Accessed 13 Mar 2019.

4. Akbar N, Gupta S, Tiwari A, Singh KP, Kumar A. Characterization of metabolic network of oxalic acid biosynthesis through RNA seq data analysis of developing spikes of finger millet (Eleusine coracana): deciphering the role of key genes involved in oxalate formation in relation to grain calcium accumul. Gene. 2018;649:40-9.

5. Ambavane AR, Sawardekar SV, Gokhale NB, Desai SAS, Sawant SS, Bhave SG, et al. Studies on mutagenic effectiveness and efficiency of finger millet [Eleucina coracana (L.) Gaertn] in M1 generation and effect of gamma rays on its quantitative traits during M2 generation. Int J Agric Sci. 2014;10:603-7.

6. Animasaun DA, Mustapha OT, Oyedeji S. Effects of nitrous acid on growth and yield of Digitaria exilis (Haller). Glob J Pure Appl Sci. 2014;20:11-6.

7. Anjaneyulu E, Reddy PS, Sunita MS, Kishor PBK, Meriga B. Salt tolerance and activity of antioxidative enzymes of transgenic finger millet overexpressing a vacuolar $\mathrm{H}+$-pyrophosphatase gene (SbVPPase) from Sorghum bicolor. J Plant Physiol. 2014;171:789-98.

8. Arora RK. Job's-tears (Coix lacryma-jobi): a minor food and fodder crop of northeastern India. Econ Bot. 1977;31:358-66.

9. Assefa K, Yu JK, Zeid M, Belay G, Tefera H, Sorrells ME. Breeding tef [Eragrostis tef (Zucc.) trotter]: conventional and molecular approaches. Plant Breed. 2011;130:1-9.

10. Austin DF. Fox-tail millets (Setaria: Poaceae): abandoned food in two hemispheres. Econ Bot. 2006;60:143-58.

11. Ayenan MAT, Sodedji KAF, Nwankwo CI, Olodo KF, Alladassi MEB. Harnessing genetic resources and progress in plant genomics for fonio (Digitaria spp.) improvement. Genet Resour Crop Evol. 2018;65:373-86.

12. Babu TK, Thakur RP, Upadhyaya HD, Reddy PN, Sharma R, Girish AG, et al. Resistance to blast (Magnaporthe grisea) in a mini-core collection of finger millet germplasm. Eur J Plant Pathol. 2013;135:299-311.

13. Baltensperger DD. Progress with proso, pearl and other millets. Trends new Crop. new uses. In: Proceedings of the fifth national symposium Atlanta, Georgia, USA, 10-13 Nov 2001. Alexandria: ASHS Press; 2002. p. 100-3.

14. Bandyopadhyay T, Muthamilarasan M, Prasad M. Millets for next generation climate-smart agriculture. Front Plant Sci. 2017;8:1266.

15. Bayer GY, Yemets AI, Blume YB. Obtaining the transgenic lines of finger millet Eleusine coracana $(\mathrm{L}$.) with dinitroaniline resistance. Cytol Genet. 2014;48:139-44.
16. Bekkering CS, Tian L. Thinking outside of the cereal box: breeding underutilized (pseudo) cereals for improved human nutrition. Front Genet. 2019;10:1289.

17. Bennetzen JL, Schmutz J, Wang H, Percifield R, Hawkins J, Pontaroli AC, et al. Reference genome sequence of the model plant Setaria. Nat Biotechnol. 2012;30:555-61.

18. Bhat BV, Tonapi VA, Rao BD, Singode A, Santra D. Production and utilization of millets in India. In: Santra DK, Johnson JJ, editors. International millet symposium on 3rd international symposium on broomcorn millet (3rd ISBM). 2018. p. 24-6.

19. Bhat S, Ganiger PC, Nandini C, Thippeswamy V. Browntop millet: a review. Agric Res Technol. 2018;14:1-2.

20. Bhave KG, Dalvi VV, Thaware BL, Mahadik SG, Kasture MC, Desai SS. Mutagenesis in proso millet (Panicum miliaceum L.). Int J Sci Res. 2016;5:1635-8.

21. Brink M, Plant Belay G. Resources of tropical Africa 1 cereals and pulses. Wageningen: PROTA Foundation/Backhuys Publishers/CYA; 2006.

22. Cakmak I, Kutman UB. Agronomic biofortification of cereals with zinc: a review. Eur J Soil Sci. 2018;69:172-80.

23. Cannarozzi G, Plaza-wüthrich S, Esfeld K, Larti S, Wilson YS, Girma D. Genome and transcriptome sequencing identifies breeding targets in the orphan crop tef (Eragrostis tef). BMC Genom. 2014;15:581.

24. Cannarozzi G, Weichert A, Schnell M, Ruiz C, Plaza-w S, Chanyalew S. Waterlogging affects plant morphology and the expression of key genes in tef (Eragrostis tef). Plant Direct. 2018;2:e0056.

25. Cao X, Wang J, Wang H, Liu S, Chen L, Tian X, et al. The complete chloroplast genome of Panicum miliaceum. Mitochondrial DNA Part B. 2017;2:43-5.

26. Ceasar SA, Baker A, Ignacimuthu S. Functional characterization of the PHT1 family transporters of foxtail millet with development of a novel Agrobacterium -mediated transformation procedure. Sci Rep. 2017;7:1-16.

27. Ceasar SA, Ignacimuthu S. Agrobacterium-mediated transformation of finger millet (Eleusine coracana (L.) Gaertn.) using shoot apex explants. Plant Cell Rep. 2011;30:1759-70.

28. Ceasar SA, Ignacimuthu S. Effects of cytokinins, carbohydrates and amino acids on induction and maturation of somatic embryos in kodo millet (Paspalum scorbiculatum Linn.). Plant Cell Tissue Organ Cult. 2010;102:153-62.

29. Ceasar SA, Ignacimuthu S. Genetic engineering of millets: current status and future prospects. Biotechnol Lett. 2009;31:779-88.

30. Ceasar SA, Rajan V, Prykhozhij SV, Berman JN, Ignacimuthu $\mathrm{S}$. Insert, remove or replace: a highly advanced genome editing system using CRISPR/Cas9. Biochim Biophys Acta Mol Cell Res. 2016;1863:2333-44.

31. Ceasar SA. Genome-wide identification and in silico analysis of PHT1 family genes and proteins in Setaria viridis: the best model to study nutrient transport in millets. Plant Genome. 2019;12:180019.

32. Chandel G, Meena RK, Dubey M, Kumar M. Nutritional properties of minor millets: neglected cereals with potentials to combat malnutrition. Curr Sci. 2014;107:1109-11.

33. Christopher J, Raj PS, Pillai KG. Cytological studies of three species of Paspalum Linn. from South India. Cytologia. 1987;52:487-91.

34. Clayton WD, Vorontsova MS, Harman KT, Williamson H. GrassBase: the online world grass flora. 2006. http://www. kew.org/data/grasses-db.html. Accessed 19 Aug 2014.

35. De Oliveira Dal'Molin CG, Orellana C, Gebbie L, Steen J, Hodson MP, Chrysanthopoulos P, et al. Metabolic reconstruction of Setaria italica: a systems biology approach for 
integrating tissue-specific omics and pathway analysis of bioenergy grasses. Front Plant Sci. 2016;7:1138.

36. de Wet JMJ, Rao KEP, Brink DE, Mengesha MH. Systematics and evolution of Eleusine coracana (Gramineae). Am J Bot. 1984;71:550-7.

37. de Wet JMJ, Rao KEP, Brink DE. Systematics and domestication of Panicum sumatrense (Graminae). J d'agriculture Tradit Bot appliquée. 1983;30:159-68.

38. de Wet JMJ, Rao KEP, Mengesha MH, Brink DE. Diversity in kodo millet, Paspalum scrobiculatum. Econ Bot. 1983;37:159-63.

39. de Wet JMJ, Rao KEP, Mengesha MH, Brink DE. Domestication of Sawa Millet (Echinochloa colona). Econ Bot. 1983;37:283-91.

40. de Wet JMJ. Origin, evolution and systematics of minor cereals. In: Seetharam A, Riley KW, Harinarayana G, editors. Small millets in global agriculture. New Delhi: Oxford \& IBH Publishing Co. Pvt. Ltd.; 1986. p. 19-30.

41. Desta EA, Hussein S, Laing M, Mengistu F, Tadele Z. Screening of ethyl methane sulphonate mutagenized tef [Eragrostis tef (Zucc.) trotter] population identifies al-tolerant lines. J Plant Interact. 2017;12:170-6.

42. Diao X, Jia G. Foxtail millet breeding in China. Genet genomics setaria (plant genet genomics crop model 19). 2017. p. 93-113.

43. Diao X. Production and genetic improvement of minor cereals in China. Crop J. 2017;5:103-14.

44. Dida MM, Srinivasachary Ramakrishnan S, Bennetzen JL, Gale MD, Devos KM. The genetic map of finger millet, Eleusine coracana. Theor Appl Genet. 2007;114:321-32.

45. Dwivedi S, Upadhyaya HD, Senthilvel S, Hash CT, Fukunaga K, Diao X, et al. Millets: genetic and genomic resources. Plant Breed Rev. 2012;35:247-375.

46. FAO. Sorghum and millets in human nutrition. FAO Food and Nutrition Series No. 27. Food and Agricultural Organization, Rome, Italy; 1995.

47. Ganapathy KN. Improvement in finger millet: Status and future prospects. In: Patil JV, editor. Millets and sorghum: biology and genetic improvement. Chichester: Wiley; 2017. p. 87-111.

48. Gebre E, Gugsa L, Schlüter U, Kunert K. Transformation of tef (Eragrostis tef) by Agrobacterium through immature embryo regeneration system for inducing semi-dwarfism. S Afr J Bot. 2013;87:9-17.

49. Goron TL, Raizada MN. Genetic diversity and genomic resources available for the small millet crops to accelerate a New Green Revolution. Front Plant Sci. 2015;6:157.

50. Gowda J, Bharathi S, Somu G, Krishnappa M, Rekha D. Formation of core set in barnyard millet [Echinochloa frumentacea (Roxb.) Link] germplasm using data on twenty four morphoagronomic traits. Int J plant Sci. 2009;4:1-5.

51. Gowda J, Rekha D, Krishnappa M. Methods of constructing core set using agro-morphological traits in foxtail millet [Setaria italica (L.) Beauv]. J Plant Genet Resour. 2007;20:193-8.

52. Gowda J, Rekha D, Somu G, Bharathi S, Krishnappa M. Development of core set in little millet (Panicum sumatrense Roth ex Roemer and Schuttes) germplasm using data on twenty one morpho-agronomic traits. Environ Ecol. 2008;26:1055-60.

53. Gowda J, Somu G, Mathur PN. Formation of core set in finger millet (Eleusine coracana (L.) Gaertn.) germplasm using geographical origin and morpho-agronomic characters. J Plant Genet Resour. 2007;20:38-42.

54. Guarino L. Global strategy for the ex situ conservation of finger millet and its wild relatives. Rome: Global Crop Diversity Trust; 2012.
55. Guo L, Qiu J, Ye C, Jin G, Mao L, Zhang H, et al. Echinochloa crus-galli genome analysis provides insight into its adaptation and invasiveness as a weed. Nat Commun. 2017;8:1031.

56. Gupta A, Sood S, Kumar P, Jagdish A, Bhatt C. Floral biology and pollination system in small millets floral biology and pollination system in small millets. Eur J Plant Sci Biotechnol. 2011;6:80-8.

57. Gupta P, Raghuvanshi S, Tyagi AK. Assessment of the efficiency of various gene promoters via biolistics in leaf and regenerating seed callus of millets, Elusine coracana and Echinochloa crusgalli. Plant Biotechnol. 2001;18:275-82.

58. Gupta R, Verma K, Joshi DC, Yadav D, Singh M. Assessment of genetic relatedness among three varieties of finger millet with variable seed coat color using RAPD and ISSR Markers. Genet Eng Biotechnol J. 2010;2:1-9.

59. Gupta SC, Muza FR, Andrews DJ. Registration of INFM 95001 finger millet genetic male-sterile line. Crop Sci. 1997;37:1409.

60. Habiyaremye C, Matanguihan JB, Guedes JD, Ganjyal GM, Whiteman MR, Kidwell KK, et al. Proso millet (Panicum miliaceum L.) and its potential for cultivation in the Pacific Northwest, U.S.: a review. Front Plant Sci. 2017;8:1961.

61. Haradari C, Gowda J, Ugalat J. Formation of core set in Indian and African finger millet [Eleusine coracana $(\mathrm{L}$.$) Gaertn] germ-$ plasm accessions. Indian J Genet Plant Breed. 2012;72:358-63.

62. Haridas BA, Ashok GS. Standardization of in vitro callus induction and regeneration protocol for mature embryo of proso millet (Panicum miliaceum L.). Int J Curr Microbiol App Sci. 2017;6:2153-63.

63. Hariprasanna K. Foxtail millet, Setaria italica (L.) P. Beauv. In: Patil JV, editor. Millets and sorghum: biology and genetic improvement, 1 st Edn. UK: John Wiley \& Sons Ltd. ISBN 978-1-119-12305-7.

64. Hariprasanna K. Kodo millet, Paspalum scrobiculatum L. In: Patil JV, editor. Millets and sorghum: biology and genetic improvement, 1 st Edn. UK: John Wiley \& Sons Ltd. p. 199-225. ISBN 978-1-119-12305-7.

65. Hatakeyama M, Aluri S, Balachadran MT, Sivarajan SR, Poveda L, Shimizu-inatsugi R, et al. Multiple hybrid de novo genome assembly of finger millet, an orphan allotetraploid crop. DNA Res. 2018;25:39-47.

66. Hema R, Vemanna RS, Sreeramulu S, Reddy CP, Senthil-kumar M, Udayakumar M. Stable expression of mtlD gene imparts multiple stress tolerance in finger millet. PLoS ONE. 2014;9:e99110.

67. Hilu KW, de Wet JMJ, Harlan JR. Archaeobotanical studies of Eleusine coracana spp. coracana (finger millet). Am J Bot. 1979;63:330-3.

68. Hilu KW, de Wet JMJ. Domestication of Eleusine coracana. Econ Bot. 1976;30:199-208.

69. Hiremath SC, Dandin SB. Cytology of Paspalum scrobiculatum Linn. Curr Sci. 1975;44:20-1.

70. Hittalmani S, Mahesh HB, Shirke MD, Biradar H, Uday G, Aruna YR, et al. Genome and transcriptome sequence of finger millet (Eleusine coracana (L.) Gaertn.) provides insights into drought tolerance and nutraceutical properties. BMC Genom. 2017; $18: 465$

71. Hunt HV, Campana MG, Lawes MC, Park Y-J, Bower MA, Howe CJ, et al. Genetic diversity and phylogeography of broomcorn millet (Panicum miliaceum L.) across Eurasia. Mol Ecol. 2011;20:4756-71.

72. Hunt HV, Vander Linden M, Liu X, Motuzaite-Matuzeviciute G, Colledge S, Jones MK. Millets across Eurasia: chronology and context of early records of the genera Panicum and Setaria from archaeological sites in the Old World. Veg Hist Archaeobot. 2008;17:5-18. 
73. Ignacimuthu S, Ceasar SA. Development of transgenic finger millet (Eleusine coracana (L.) Gaertn.) resistant to leaf blast disease. J Biosci. 2012;37:135-47.

74. Jagga-Chugh S, Kachhawaha S, Sharma M, Kothari-Chajer A, Kothari SL. Optimization of factors influencing microprojectile bombardment-mediated genetic transformation of seed-derived callus and regeneration of transgenic plants in Eleusine coracana (L.) Gaertn. Plant Cell Tissue Organ Cult. 2012;109:401-10.

75. Jaiswal V, Bandyopadhyay T, Gahlaut V, Gupta S, Dhaka A, Ramchiary N, et al. Genome-wide association study (GWAS) delineatess genomic loci for ten nutritional elements in foxtail millet (Setaria italica L.). J Cereal Sci. 2019;85:48-55.

76. Jaiswal V, Gupta S, Gahlaut V, Muthamilarasan M. Genomewide association study of major agronomic traits in foxtail millet (Setaria italica L.) using ddRAD sequencing. Sci Rep. 2019;9:5020.

77. Jayakodi M, Madheswaran M, Adhimoolam K, Perumal S, Manicum D, Kandasamy T, et al. Transcriptomes of Indian barnyard millet and barnyardgrass reveal putative genes involved in drought adaptation and micronutrient accumulation. Acta Physiol Plant. 2019;41:66.

78. Jayasudha BG, Sushma AM, Prashantkumar HS, Sashidhar VR. An efficient in vitro agrobacterium -mediated transformation protocol for raising salinity tolerant transgenic plants in finger millet [Eleusine coracana (L.) Gaertn.]. Plant Arch. 2014;14:823-9.

79. Jency JP, Ravikesavan R, Sumathi P, Raveendran M. Determination of lethal dose and effect of physical mutagen on germination percentage and seedling parameters in kodomillet variety $\mathrm{CO}_{3}$. Int J Chem Stud. 2016;5:166-9.

80. Jia G, Huang X, Zhi H, Zhao Y, Zhao Q, Li W, et al. A haplotype map of genomic variations and genome-wide association studies of agronomic traits in foxtail millet (Setaria italica). Nat Genet. 2013;45:957-61.

81. Johnson M, Deshpande S, Vetriventhan M, Upadhyaya HD, Wallace JG. Genome-wide population structure analyses of three minor millets: kodo millet, little millet, and proso millet. Plant Genome. 2019;12:190021.

82. Joshi DC, Chaudhari GV, Sood S, Kant L, Pattanayak A, Zhang K, et al. Revisiting the versatile buckwheat: reinvigorating genetic gains through integrated breeding and genomics approach. Planta. 2019;250:783-801.

83. Kam J, Puranik S, Yadav R, Manwaring HR, Pierre S, Srivastava RK, et al. Dietary interventions for type 2 diabetes: how millet comes to help. Front Plant Sci. 2016;7:1-14.

84. Kaur P, Kothari SL. Embryogenic callus induction and efficient plant regeneration from root cultures of kodo millet. Phytomorphology. 2003;53:49-56.

85. Kaur P, Kothari SL. In vitro culture of kodo millet: influence of 2,4-D and picloram in combination with kinetin on callus initiation and regeneration. Plant Cell Tissue Organ Cult. 2004;77:73-9.

86. Krishnamurthy L, Upadhyaya HD, Gowda CLL, Kashiwagi J, Purushothaman R, Singh S, et al. Large variation for salinity tolerance in the core collection of foxtail millet (Setaria italica (L.) P. Beauv.) germplasm. Crop Pasture Sci. 2014;65:353-61.

87. Krishnamurthy L, Upadhyaya HD, Kashiwagi J, Purushothaman $\mathrm{R}$, Dwivedi SL, Vadez V. Variation in drought-tolerance components and their interrelationships in the minicore collection of finger millet germplasm. Crop Sci. 2016;56:1914-26.

88. Krishnamurthy L, Upadhyaya HD, Kashiwagi J, Purushothaman R, Dwivedi SL, Vadez V. Variation in drought-tolerance components and their interrelationships in the core collection of foxtail millet (Setaria italica) germplasm. Crop Pasture Sci. 2016;67:834-46.

89. Krishnamurthy L, Upadhyaya HD, Purushothaman R, Gowda CLL, Kashiwagi J, Dwivedi SL, et al. The extent of variation in salinity tolerance of the minicore collection of finger millet (Eleusine coracana L. Gaertn.) germplasm. Plant Sci. 2014;227:51-9.

90. Kumari K, Muthamilarasan M, Misra G, Gupta S, Subramanian A, Parida SK, et al. Development of eSSR-markers in Setaria italica and Their applicability in studying genetic diversity, cross-transferability and comparative mapping in millet and nonmillet species. PLoS ONE. 2013;8:e67742.

91. Lata C, Mishra AK, Muthamilarasan M, Bonthala VS, Khan Y, Prasad M. Genome-wide investigation and expression profiling of AP2/ERF transcription factor superfamily in foxtail millet (Setaria italica L.). PLoS ONE. 2014;9:e113092.

92. Latha AM, Rao KV, Reddy VD. Production of transgenic plants resistant to leaf blast disease in finger millet (Eleusine coracana (L.) Gaertn.). Plant Sci. 2005;169:657-67.

93. Lee H. Teff, a rising global crop: current status of teff production and value chain. Open Agric J. 2018;12:185-93.

94. Li C, Yue J, Wu X, Xu C, Yu J. An ABA-responsive DRE-binding protein gene from Setaria italica, SiARDP, the target gene of SiAREB, plays a critical role under drought stress. J Exp Bot. 2014;65:5415-27.

95. Li HW, Li CH, Pao WK. Cytological and genetical studies of the interspecific cross of the cultivated foxtail millet, Setaria italica (L.) Beauv., and the green foxtail millet, S. viridis L. J Am Soc Agron. 1945;37:32-54.

96. Li HW, Meng CJ, Liu TN. Problems in the breeding of millet (Setaria italica (L.) Beauv.). J Am Soc Agron. 1935;27:963-70.

97. Li J, Dong Y, Li C, Pan Y, Yu J. SiASR4, the target gene of SiARDP from Setaria italica, improves abiotic stress adaption in plants. Front Plant Sci. 2017;7:2053.

98. Li J, Li X, Yang Q, Luo Y, Gong X, Zhang W, et al. Proteomic changes in the grains of foxtail millet (Setaria italica (L.) beau) under drought stress. Span J Agric Res. 2019;17:e0802.

99. Li R, Han Y, Zhang Q, Chang G, Han Y, Li X, et al. Transcriptome profiling analysis reveals co-regulation of hormone pathways in foxtail millet during Sclerospora graminicola infection. Int J Mol Sci. 2020;21:1226.

100. Li S, Dong X, Fan G, Yang Q, Shi J, Wei W, et al. Comprehensive profiling and inheritance patterns of metabolites in foxtail millet. Front Plant Sci. 2018;871:1-16.

101. Li W, Chen M, Wang E, Hu L, Hawkesford MJ, Zhong L, et al. Genome-wide analysis of autophagy-associated genes in foxtail millet (Setaria italica L.) and characterization of the function of SiATG8a in conferring tolerance to nitrogen starvation in rice. BMC Genomics. 2016;17:797.

102. Li X, Siddique KHM. Future smart food: rediscovering hidden treasures of neglected and underutilized species for zero hunger in Asia. Bangkok: Food and Agriculture Organisation of the United Nations; 2018.

103. Lim TK. Coix lachryma-jobi. In: Lim TK, editor. Edible medicinal and non-medicinal plants. Dordrecht: Springer; 2013

104. Lin CS, Hsu CT, Yang LH, Lee LY, Fu JY, Cheng QW, et al. Application of protoplast technology to CRISPR/Cas9 mutagenesis: from single-cell mutation detection to mutant plant regeneration. Plant Biotechnol J. 2018;16:1295-310.

105. Liu Y, Feng X, Xu Y, Yu J, Ao G, Peng Z, et al. Overexpression of millet ZIP-like gene (SiPf40) affects lateral bud outgrowth in tobacco and millet. Plant Physiol Biochem. 2009;47:1051-60.

106. Liu Y, Yu J, Zhao Q, Zhu D, Ao G. Genetic transformation of millet (Setaria italica) by Agrobacterium-mediated. J Agric Biotechnol. 2005;13:32-7.

107. Liu Z, Zhang T, Li C, Bai G. Genetic diversity and classification of cytoplasm of Chinese elite foxtail millet [Setaria italica (L.) P. Beauv.] germplasm. Crop Sci. 2014;54:659-66.

108. Lu H, Zhang J, Liu K, Wu N, Li Y, Zhou K, et al. Earliest domestication of common millet (Panicum miliaceum) in East 
Asia extended to 10,000 years ago. Proc Natl Acad Sci U S A [Internet]. 2009;106:7367-72.

109. Mahalakshmi S, Christopher GSB, Reddy TP, Rao KV, Reddy VD. Isolation of a cDNA clone (PcSrp) encoding serine-richprotein from Porteresia coarctata $\mathrm{T}$. and its expression in yeast and finger millet (Eleusine coracana L.) affording salt tolerance. Planta. 2006;224:347-59.

110. Merga M. Progress, achievements and challenges of Tef breeding in Ethiopia. J Agric Sci Food Res. 2018;9:1000204.

111. Mishra AK, Muthamilarasan M, Khan Y, Parida SK, Prasad M. Genome-wide investigation and expression analyses of WD40 protein family in the model plant foxtail millet (Setaria italica L.). PLoS ONE. 2014;9:e86852.

112. Mishra M. Studies on in vitro regeneration of panicum sumatrence using mature seed and leaf base explant. Jabalpur: Jawaharlal Nehru Krishi Vishwa Vidyalaya; 2017.

113. Muduli KC, Misra RC. Efficacy of mutagenic treatments in producing useful mutants in finger millet (Eleusine coracana Gaertn.). Indian J Genet Plant Breed. 2007;67:232-7.

114. Muthamilarasan M, Bonthala VS, Khandelwal R, Jaishankar J, Shweta S, Nawaz K, et al. Global analysis of WRKY transcription factor superfamily in Setaria identifies potential candidates involved in abiotic stress signaling. Front Plant Sci. 2015;6:910.

115. Muthamilarasan M, Bonthala VS, Mishra AK, Khandelwal R, Khan Y, Roy R, et al. $\mathrm{C}_{2} \mathrm{H}_{2}$ type of zinc finger transcription factors in foxtail millet define response to abiotic stresses. Funct Integr Genomics. 2014;14:531-43.

116. Muthamilarasan M, Khandelwal R, Yadav CB, Bonthala VS, Khan Y, Prasad M. Identification and molecular characterization of MYB transcription factor superfamily in $\mathrm{C}_{4}$ model plant foxtail millet (Setaria italica L.). PLoS ONE. 2014;9:e109920.

117. Muthamilarasan M, Mangu VR, Zandkarimi H, Prasad M, Baisakh N. Structure, organization and evolution of ADP-ribosylation factors in rice and foxtail millet, and their expression in rice. Sci Rep. 2016;6:srep24008.

118. Muthamilarasan M, Singh NK, Prasad M. Chapter one: multiomics approaches for strategic improvement of stress tolerance in underutilized crop species: a climate change perspective. Adv Genet. 2019;103:1-38.

119. Nagaraja A, Jagadish PS, Ashok EG, Gowda KTK. Avoidance of finger millet blast by ideal sowing time and assessment of varietal performance under rain fed production situations in Karnataka. J Mycopathol Res Calcutta Indian Mycol Soc. 2007;45:237-40.

120. Nah G, Im J, Kim J, Park H, Yook M, Yang T-J, et al. Uncovering the differential molecular basis of adaptive diversity in three Echinochloa leaf transcriptomes. PLoS ONE. 2015;10:e0134419.

121. Nelson LA. Technique for crossing proso Millet. Crop Sci. 1984;24:205-6.

122. Nie X, Zhao X, Wang S, Zhang T, Li C, Liu H, et al. Complete chloroplast genome sequence of broomcorn millet (Panicum miliaceum L.) and comparative analysis with other Panicoideae species. Agronomy. 2018;8:159.

123. Nigus C. Genetic variation of tef [Eragrostis tef (Zucc.) Trotter] genotypes for reaction to tef shoot fly [Atherigona hyalinipennis Van Emde], at Maysiye, Northern Ethiopia. J Plant Breed Crop Sci. 2018;10:146-52.

124. Nkhata SG, Ayua E, Kamau EH, Shingiro JB. Fermentation and germination improve nutritional value of cereals and legumes through activation of endogenous enzymes. Food Sci Nutr. 2018;6:2446-58.

125. NRC. Lost crops of Africa: vol 1: Grains. National Academy Press; 1996. https://doi.org/10.17226/2305.

126. Ntui VO, Uyoh EA, Nakamura I, Mii M. Agrobacterium-mediated genetic transformation of Fonio (Digitaria exilis (L.) Stapf). Afr J Biotechnol. 2017;16:1302-7.
127. Pan Y, Li J, Jiao L, Li C, Zhu D, Yu J. A non-specific Setaria italica lipid transfer protein gene plays a critical role under abiotic stress. Front Plant Sci. 2016;7:1752.

128. Pan Y, Ma X, Liang H. Spatial and temporal activity of the foxtail millet (Setaria italica) seed-specific promoter pF128. Planta. 2015;241:57-67.

129. Pandey G, Misra G, Kumari K, Gupta S, Parida SK, Chattopadhyay D, et al. Genome-wide development and use of microsatellite markers for large-scale genotyping applications in foxtail millet [Setaria italica (L.)]. DNA Res. 2013;20:197-207.

130. Panwar P, Dubey A, Verma AK. Evaluation of nutraceutical and antinutritional properties in barnyard and finger millet varieties grown in Himalayan region. J Food Sci Technol. 2016;53:2779-87.

131. Park $\mathrm{CH}$. Production and utilization of broomcorn millet in korea. In: Santra DK, Johnson JJ, editors. International millet symposium 3rd international symposium on broomcorn millet (3rd ISBM) Progr Abstr. 2018. p. 27.

132. Parvathi MS, Nataraja KN, Reddy YAN, Naika MBN, Gowda MVC. Transcriptome analysis of finger millet (Eleusine coracana (L.) Gaertn.) reveals unique drought responsive genes. J Genet. 2019;98:46.

133. Perumal S, Jayakodi M, Kim D, Yang T. The complete chloroplast genome sequence of Indian barnyard millet, Echinochloa frumentacea (Poaceae). Mitochondrial DNA Part B. 2016;2359:4-6.

134. Puranik S, Sahu PP, Mandal SN, Suresh BV, Parida SK, Prasad M. Comprehensive genome-wide survey, genomic constitution and expression profiling of the NAC transcription factor family in foxtail millet (Setaria italica L.). PLoS ONE. 2013;8:e64594.

135. Qin FF, Zhan Q, Ao GM, Yu JJ. Co-suppression of Si401, a maize pollen specific $\mathrm{Zm} 401$ homologous gene, results in aberrant anther development in foxtail millet. Euphytica. 2008;163:103-11.

136. Rahman H, Jagadeeshselvam N, Valarmathi R, Sachin B, Sasikala $\mathrm{R}$, Senthil N, et al. Transcriptome analysis of salinity responsiveness in contrasting genotypes of finger millet (Eleusine coracana L.) through RNA-sequencing. Plant Mol Biol. 2014;85:485-503.

137. Rajak K, Sprae S, Kumari R, Tiwari N. To study the indirect plant regeneration of two cultivars in barnyard millet using different combination of plant growth regulators and compared between superior genotype for in vitro culture. Int J Curr Microbiol App Sci. 2018;6:2055-61.

138. Rajak K, Tiwari N, Kumari R. Standardize protocol for callus induction and plant regeneration in barnyard millet using different combination of plant growth regulators. Int J Curr Microbiol App Sci. 2018;6:2590-6.

139. Rajput SG, Plyler-harveson T, Santra DK. Development and characterization of SSR markers in proso millet based on switchgrass genomics. Am J Plant Sci. 2014;5:175-86.

140. Rajput SG, Santra DK, Schnable J. Mapping QTLs for morphoagronomic traits in proso millet (Panicum miliaceum L.). Mol Breed. 2016;36:37.

141. Ramakrishnan M, Ceasar SA, Vinod KK, Duraipandiyan V, Krishna TPA, Upadhyaya HD, et al. Identification of putative QTLs for seedling stage phosphorus starvation response in finger millet (Eleusine coracana L. Gaertn.) by association mapping and cross species synteny analysis. PLoS ONE. 2017;12:e0183261.

142. Ramegowda Y, Venkategowda R, Jagadish P, Govind G, Hanumanthareddy RR, Makarla U, et al. Expression of a rice Zn transporter, OsZIP1, increases $\mathrm{Zn}$ concentration in tobacco and finger millet transgenic plants. Plant Biotechnol Rep. 2013;7:309-19. 
143. Rao ANS. Estimates of losses in finger millet (Eleusine coracana) due to blast disease (Pyricularia grisea). Mysore J Agric Sci. 1990;24:57-60.

144. Rao KEP, de Wet JMJ, Brink DE, Mengesha MH. Infraspecific variation and systematics of cultivated Setaria italica, foxtail millet (Poaceae). Econ Bot. 1987;41:108-16.

145. Saleh ASM, Zhang Q, Chen J, Shen Q. Millet grains: nutritional quality, processing, and potential health benefits. Compr Rev Food Sci Food Saf. 2013;12:281-95.

146. Santra DK, Khound R, Das S. Proso Millet (Panicum miliaceum L.) breeding: progress, challenges and opportunities. In: Al-Khayri J, Jain SM, Johnson DV, editors. Advances in plant breeding strategies: cereals. Cham: Springer; 2019. p. 223-57.

147. Santra DK. Proso millet varieties for western Nebraska. Lincoln: NebGuide, University of Nebraska; 2013. p. G2219.

148. Satheesh N, Fanta SW. Review on structural, nutritional and antinutritional composition of Teff (Eragrostis tef) in comparison with Quinoa (Chenopodium quinoa Willd.). Cogent Food Agric. 2018;4:1546942.

149. Satish L, Ceasar SA, Ramesh M. Improved Agrobacteriummediated transformation and direct plant regeneration in four cultivars of finger millet (Eleusine coracana (L.) Gaertn). Plant Cell Tissue Organ Cult. 2017;131:547-65.

150. Saxena R, Vanga SK, Wang J, Orsat V, Raghavan V. Millets for food security in the context of climate change: a review. Sustainability. 2018;10:2228.

151. Sebastin R, Lee G, Lee KJ, Shin M, Lee J, Ma K, et al. The complete chloroplast genome sequences of little millet (Panicum sumatrense Roth ex Roem. and Schult.) (Poaceae). Mitochondrial DNA Part B. 2018;3:719-20.

152. Sebastin R, Lee KJ, Cho G, Lee J, Kim S, Lee G, et al. The complete chloroplast genome sequence of Japanese millet Echinochloa esculenta (A. braun) H. scholz (Poaceae). Mitochondrial DNA Part B. 2019;4:1392-3.

153. Sharma D, Tiwari A, Sood S, Jamra G, Singh NK. Genome wide association mapping of agro- morphological traits among a diverse collection of finger millet (Eleusine coracana L.) genotypes using SNP markers. PLoS One. 2018;13:e0199444.

154. Sharma M, Kothari-Chajer A, Jagga-Chugh S, Kothari SL. Factors influencing Agrobacterium tumefaciens-mediated genetic transformation of Eleusine coracana (L.) Gaertn. Plant Cell Tissue Organ Cult. 2011;105:93-104.

155. Sharma R, Girish AG, Upadhyaya HD, Humayun P, Babu TK, Rao VP, et al. Identification of blast resistance in a core collection of foxtail millet germplasm. Plant Dis. 2014;98:519-24.

156. Shi J, Ma X, Zhang J, Zhou Y, Liu M, Huang L, et al. Chromosome conformation capture resolved near complete genome assembly of broomcorn millet. Nat Commun. 2019;10:464.

157. Shuo W, LiZhi G. The complete chloroplast genome of an irreplaceable dietary and model crop, foxtail millet (Setaria italica). Mitochondrial DNA Part A. 2016;27:4442-3.

158. Siles MM, Baltensperger DD, Nelson LA. Technique for artificial hybridization of foxtail millet [Setaria italica (L.) Beauv.]. Crop Sci. 2001;41:1408-12.

159. Singh M, Metwal M, Kumar VA, Kumar A. Identification and molecular characterization of $48 \mathrm{kDa}$ calcium binding protein as calreticulin from finger millet (Eleusine coracana) using peptide mass fingerprinting and transcript profiling. J Sci Food Agric. 2016;96:672-9.

160. Singh RK, Jaishankar J, Muthamilarasan M, Shweta S, Dangi A, Prasad M. Genome-wide analysis of heat shock proteins in $\mathrm{C}_{4}$ model, foxtail millet identifies potential candidates for crop improvement under abiotic stress. Sci Rep. 2016;6:32641.

161. Tian B, Luan S, Zhang L, Liu Y, Zhang L, Li H. Penalties in yield and yield associated traits caused by stem lodging at different developmental stages in summer and spring foxtail millet cultivars. Field Crop Res. 2018;217:104-12.

162. Tian B, Wang J, Zhang L, Li Y, Wang S, Li H. Assessment of resistance to lodging of landrace and improved cultivars in foxtail millet. Euphytica. 2010;172:295-302.

163. Upadhyaya HD, Dwivedi SL, Singh SK, Singh S, Vetriventhan M, Sharma S. Forming core collections in barnyard, kodo, and little millets using morphoagronomic descriptors. Crop Sci. 2014;54:2673-82.

164. Upadhyaya HD, Gowda CLL, Pundir RPS, Reddy VG, Singh S. Development of core subset of finger millet germplasm using geographical origin and data on 14 quantitative traits. Genet Resour Crop Evol. 2006;53:679-85.

165. Upadhyaya HD, Pundir RPS, Gowda CLL, Reddy VG, Singh S. Establishing a core collection of foxtail millet to enhance the utilization of germplasm of an underutilized crop. Plant Genet Resour Charact Util. 2008;7:177-84.

166. Upadhyaya HD, Ramesh S, Sharma S, Singh SK, Varshney SK, Sarma NDRK, et al. Genetic diversity for grain nutrients contents in a core collection of finger millet (Eleusine coracana $(\mathrm{L}$. Gaertn.) germplasm. Field Crop Res. 2011;121:42-52.

167. Upadhyaya HD, Ravishankar CR, Narasimhudu Y, Sarma NDRK, Singh SK, Varshney SK, et al. Identification of traitspecific germplasm and developing a mini core collection for efficient use of foxtail millet genetic resources in crop improvement. Field Crop Res. 2011;124:459-67.

168. Upadhyaya HD, Sarma NDRK, Ravishankar CR, Albrecht T, Narasimhudu Y, Singh SK, et al. Developing a mini-core collection in finger millet using multilocation data. Crop Sci. 2010;50:1924-31.

169. Upadhyaya HD, Sharma S, Gowda CLL, Reddy VG, Singh S. Developing proso millet (Panicum miliaceum L.) core collection using geographic and morpho-agronomic data. Crop Pasture Sci. 2011;62:383-9.

170. Upadhyaya HD, Vetriventhan M, Deshpande SP, Sivasubramani S, Wallace JG, Buckler ES, et al. Population genetics and structure of a global foxtail millet germplasm collection. Plant Genome. 2015;8(3):1-13.

171. Upadhyaya HD, Vetriventhan M, Dwivedi SL, Pattanashetti SK, Singh SK. Proso, barnyard, little and kodo millets. In: Singh M, Upadhyaya HD, editors. Genet genomic resour grain cereal improv. Oxford: Academic Press; 2015. p. 321-43.

172. VanBuren R, Man Wai C, Wang X, Pardo J, Yocca AE, Wang H, et al. Exceptional subgenome stability and functional divergence in the allotetraploid Ethiopian cereal teff. Nat Commun. 2020;11:884.

173. Vavilov NI. The origin, variation, immunity and breeding of cultivated plants. Chronica Botonica 1951;13:1-366. (Translated by S. K. Chestitee)

174. Veeranagamallaiah G, Jyothsnakumari G, Thippeswamy M, Reddy PCO, Surabhi GK, Sriranganayakulu G, et al. Proteomic analysis of salt stress responses in foxtail millet (Setaria italica L. cv. Prasad) seedlings. Plant Sci. 2008;175:631-41.

175. Vetriventhan M, Upadhyaya HD, Dwived SL, Pattanashetti SK, Singh SK. 7-Finger and foxtail millets. In: Singh M, Upadhyaya HD, editors. Genetic and genomic resources for grain cereals improvement. San Diego: Academic Press; 2016. p. 291-319. https://doi.org/10.1016/B978-0-12-802000-5.00007-1

176. Vetriventhan M, Upadhyaya HD. Diversity and trait-specific sources for productivity and nutritional traits in the global proso millet (Panicum miliaceum L.) germplasm collection. Crop J. 2018;6:451-63.

177. Vetriventhan M, Upadhyaya HD. Variability for productivity and nutritional traits in germplasm of kodo millet, an underutilized nutrient-rich climate smart crop. Crop Sci. 2019;59:1095-106.

178. Vinoth A, Ravindhran R. Biofortification in millets: a sustainable approach for nutritional security. Front Plant Sci. 2017;8:29. 
179. Wallace JG, Upadhyaya HD, Vetriventhan M, Buckler ES, Hash CT, Ramu P. The genetic makeup of a global barnyard millet germplasm collection. Plant Genome. 2015;8(1):1-7.

180. Wang J, Wang Z, Yang H, Yuan F, Guo E, Tian G, et al. Genetic analysis and preliminary mapping of a highly male-sterile gene in foxtail Millet (Setaria italica L. Beauv.) using SSR markers. J Integr Agric. 2013;12:2143-8.

181. Wang M, Li P, Li C, Pan Y, Jiang X, Zhu D, et al. SiLEA14, a novel atypical LEA protein, confers abiotic stress resistance in foxtail millet. BMC Plant Biol. 2014;14:290.

182. Wang M, Pan Y, Li C, Liu C, Zhao Q, Ao G. Culturing of immature inflorescences and Agrobacterium-mediated transformation of foxtail millet (Setaria italica). Afr J Biotechnol. 2011;10:16466-79.

183. Wang RL, Wendel JF, Dekker JH. Weedy adaptation in Setaria spp. I. Isozyme analysis of genetic diversity and population genetic structure in Setaria viridis. Am J Bot. 1995;82:308-17.

184. Wang ZM, Devos KM, Liu CJ, Wang RQ, Gale MD. Construction of RFLP-based maps of foxtail millet, Setaria italica (L.) P. Beauv. Theor Appl Genet. 1998;96:31-6.

185. Welch RM. Cereal grains. In: Caballero B, Allen L, Prentice A, editors. Encyclopedia of human nutrition. 2nd ed. Amsterdam: Elsevier; 2005. p. 346-57.

186. Yadav CB, Muthamilarasan M, Pandey G, Khan Y, Prasad M. Development of novel microRNA-based genetic markers in foxtail millet for genotyping applications in related grass species. Mol Breed. 2014;34:2219-24.

187. Yadav CB, Muthamilarasan M, Pandey G, Prasad M. Identification, characterization and expression profiling of dicer-like, argonaute and rna-dependent RNA polymerase gene families in foxtail millet. Plant Mol Biol Rep. 2015;33:43-55.

188. Yang R, Chen M, Sun J, Yu Y, Min D, Chen J, et al. Genomewide analysis of LIM family genes in foxtail millet (Setaria italica L.) and characterization of the Role of SiWLIM2b in drought tolerance. Int J Mol Sci. 2019;20:1303.

189. Yang X, Wan Z, Perry L, Lu H, Wang Q, Zhao C, et al. Early millet use in northern China. Proc Natl Acad Sci. 2012;109:3726-30.

190. Ye CY, Lin Z, Li G, Wang YY, Qiu J, Fu F, et al. Echinochloa chloroplast genomes: insights into the evolution and taxonomic identification of two weedy species. PLoS ONE. 2014;9:1-16.

191. Yu TF, Zhao WY, Fu JD, Liu YW, Chen M, Bin Zhou Y, et al. Genome-wide analysis of CDPK family in foxtail millet and determination of SiCDPK24 functions in drought stress. Front Plant Sci. 2018;9:651

192. Yuan J, Wei H, Liu Y, Dong Z. Agrobacterium-mediated transformation of millet [Setaria italica (L.)] using mature seeds. Res J Biotechnol. 2013;8:83-90.

193. Yue H, Wang L, Liu H, Yue W, Du X, Song W, et al. De novo assembly and characterization of the transcriptome of broomcorn millet (Panicum miliaceum L.) for gene discovery and marker development. Front Plant Sci. 2016;7:1-13.

194. Zhang G, Liu X, Quan Z, Cheng S, Xu X, Pan S, et al. Genome sequence of foxtail millet (Setaria italica) provides insights into grass evolution and biofuel potential. Nat Biotechnol. 2012;30:549-54.

195. Zhao W, Liu YW, Zhou JM, Zhao SP, Zhang XH, Min DH. Genome-wide analysis of the lectin receptor-like kinase family in foxtail millet (Setaria italica L.). Plant Cell Tissue Organ Cult. 2016;127:335-46.

196. Zou C, Li L, Miki D, Li D, Tang Q, Xiao L, et al. The genome of broomcorn millet. Nat Commun. 2019;10:436.

Publisher's Note Springer Nature remains neutral with regard to jurisdictional claims in published maps and institutional affiliations.

\section{Affiliations}

\section{Vetriventhan ${ }^{1}$ (1) - Vania C. R. Azevedo ${ }^{1}$ H. D. Upadhyaya ${ }^{1,9} \cdot$ A. Nirmalakumari ${ }^{2}$. Joanna Kane-Potaka ${ }^{1}$. S. Anitha ${ }^{1} \cdot$ S. Antony Ceasar ${ }^{3} \cdot$ M. Muthamilarasan ${ }^{4} \cdot$ B. Venkatesh Bhat ${ }^{5} \cdot$ K. Hariprasanna ${ }^{5}$. Amasiddha Bellundagi ${ }^{5}$. Deepika Cheruku ${ }^{5}$. C. Backiyalakshmi ${ }^{6}$. Dipak Santra ${ }^{7}$. C. Vanniarajan ${ }^{8}$. Vilas A. Tonapi ${ }^{5}$}

1 International Crops Research Institute for the Semi-Arid Tropics (ICRISAT), Patancheru, Telangana 502 324, India

2 Centre of Excellence in Millets, Tamil Nadu Agricultural University (TNAU), Athiyandal, Tiruvannamalai, Tamil Nadu 606 603, India

3 Division of Plant Biotechnology, Entomology Research Institute, Loyola College, Chennai 600 034, India

4 Department of Plant Sciences, School of Life Sciences, University of Hyderabad, Hyderabad, Telangana 500 046, India

5 Indian Institute of Millets Research, Rajendranagar, Hyderabad, Telangana 500 030, India
6 Agricultural College and Research Institute, Tamil Nadu Agricultural University (TNAU), Coimbatore, Tamil Nadu 641 003, India

7 Panhandle Research and Extension Center, University of Nebraska-Lincoln, 4502 Ave I, Scottsbluff, NE 69361, USA

8 Agricultural College and Research Institute, Tamil Nadu Agricultural University (TNAU), Madurai, Tamil Nadu 625 104, India

9 Present Address: The University of Georgia, 111 Riverbend Road, Athens, GA 30605, USA 